\title{
24. GEOMETRY OF PLEISTOCENE FACIES ON THE GREAT BARRIER REEF OUTER SHELF AND UPPER SLOPE-SEISMIC STRATIGRAPHY OF SITES 819, 820, AND 821 ${ }^{1}$
}

\author{
David A. Feary, ${ }^{2}$ Phillip A. Symonds, ${ }^{2}$ Peter J. Davies,${ }^{3}$ Christopher J. Pigram, ${ }^{2}$ and Richard D. Jarrard ${ }^{4}$
}

\begin{abstract}
Seismic stratigraphic analysis of the sedimentary succession intersected in Ocean Drilling Program (ODP) Sites 819, 820, and 821 , on the outer shelf and upper slope seaward of the Great Barrier Reef, provides a clear indication of the importance of sediment supply and depositional base-level as two of the fundamental parameters that control the geometry of seismic sequences. The nine predominantly unconformity-bounded seismic sequences display two different geometric styles: obliquely progradational sequences at the base of the succession are succeeded by purely aggradational sequences. The distribution of the aggradational sequences shows that deposition was concentrated on the outer shelf, with the locus of sedimentation varying from the shelf edge to immediately adjacent to the Great Barrier Reef. The locus of deposition of the underlying obliquely progradational sequences was predominantly within broad submarine valleys immediately below the paleoshelf edge. Depositional base-level fluctuations controlled the textural and compositional characteristics of sediment that was deposited on the outer shelf and upper slope, and formed sequence and subsequence boundaries characterized by offlap and/or onlap. However, it was the initiation of reef growth to form an outer reef barrier, at approximately 0.75 to $1 \mathrm{Ma}$, that restricted sediment supply to the outer shelf and resulted in the two fundamentally different types of seismic sequence geometry.
\end{abstract}

\section{INTRODUCTION}

Determining the factors that controlled the development of the carbonate platforms off the northeastern Australia passive continental margin has been a major focus of geological and geophysical studies by the Australian Geological Survey Organisation (AGSO-formerly the Bureau of Mineral Resources [BMR]) since the 1970s. During this research, the Great Barrier Reef and the Queensland, Marion, and Eastern plateaus were recognized as providing an unparalleled record of the initiation, development, and demise of carbonate platforms and of the dynamic interactions among the factors that controlled reef growth (Davies, 1983; Symonds et al., 1983; Davies et al., 1989; Feary et al., 1991). The conclusion from these earlier studies of the Great Barrier Reef was that the reef sequence thins and the age of initial reef growth becomes younger from north to south (Davies et al., 1987; 1989). Prior to ODP drilling, tentative seismic ties indicated that the base of the reefal sequence in the central Great Barrier Reef was probably of Pliocene age, and overlay siliciclastic fluvio-deltaic deposits (Symonds et al., 1983; Davies et al., 1989; Feary et al., 1990).

The central Great Barrier Reef shelf is a narrow, partially rimmed, high-energy platform, $50-75 \mathrm{~km}$ wide, with a steep continental slope (Davies et al., 1989). Reefs generally occur on the middle to outer shelf, and the outer reefal barrier consists of a semi-continuous line of ribbon reefs and shoals separated by passages. The recognition of an apparently sea-level-controlled progradational succession (Symonds et al., 1983) immediately seaward of the central Great Barrier Reef in Grafton Passage, off Cairns (Fig. 1), provided the basis for proposed ODP drilling to determine the relationships between seismic geometries, sedimentary facies, and eustatic variations in sea-level.

Following the initial identification of drilling targets, the AGSO recorded a $140 \mathrm{~km}$ grid of water-gun seismic data within an area of $100 \mathrm{~km}^{2}$ (Fig. 2) to further refine drill-site locations for both scientific and site safety purposes. The moderately high resolution of this seis-

\footnotetext{
${ }^{1}$ McKenzie, J.A., Davies, P.J., Palmer-Julson, A., et al., 1993.Proc. ODP, Sci. Results 133: College Station, TX (Ocean Drilling Program).

${ }^{2}$ Division of Marine Geosciences and Petroleum Geology. Australian Geological Survey Organisation (formerly Bureau of Mineral Resources), Canberra, Australia.

${ }^{3}$ Department of Geology and Geophysics, University of Sydney, Sydney, Australia. U.S.A.

${ }^{4}$ Department of Geology and Geophysics, University of Utah, Salt Lake City, UT,
}

mic data, as a consequence of its broad frequency spectrum, together with the close line spacing within the grid $(1-1.5 \mathrm{~km})$, provided the basis for analysis of the three-dimensional geometry and seismic facies characteristics of the sedimentary succession that comprises the outer shelf and upper slope, immediately seaward of the presentday Great Barrier Reef.

During September 1990, the drilling crew of the JOIDES Resolution drilled Sites 819 to 821 , each to a total depth of $400 \mathrm{~m}$, on the outer shelf and upper slope adjacent to Grafton Passage (Fig. 2). Lithofacies recovered from these sites consisted of a relatively uniform suite of greenish-gray, clayey, calcareous mudstones and bioclastic wackestones/packstones (Davies, McKenzie, Palmer-Julson, et al., 1991). Contrary to predictions prior to drilling (Feary et al., 1990), no significant increase in siliciclastic detritus occurred in lower parts of the holes, corresponding to the progradational seismic intervals, and the drilled succession was entirely of Pleistocene age. The correspondence between lithofacies logs and seismic sequences for each site (Fig. 3) was determined using synthetic seismograms derived from downhole logging. As a consequence, detailed faunal (Wei and Gartner, this volume) and sedimentologic (Feary and Jarrard, this volume; Peerdeman and Davies, this volume) analyses of the drilled succession can be related to seismic data. The combination of high-resolution seismic, biostratigraphic, and sedimentary records provides the opportunity to determine the factors that controlled the distribution and characteristics of the seismic sequences. First, we present detailed descriptions of the geometry, stratal characteristics, and corresponding age and lithofacies for each seismic sequence. By integrating these descriptions with paleodepth data, we demonstrate the relationship between seismic characteristics and fluctuations of both depositional base-level and sediment supply. Although it is clear that depositional base-level is a fundamental control on lithofacies and stratal geometry, we were unable to interpret the seismic sequence in terms of systems tracts (Brown and Fisher, 1977; Jervey, 1988; Sarg, 1988) because of profound differences in scale; lithofacies analysis (Feary and Jarrard, this volume) shows that most seismic reflector cycles represent three 5th-order (Vail et al., 1977b) systems tracts in the sedimentary succession, or alternatively, the entire succession falls within a single 3rdorder composite sequence (Van Wagoner et al., 1990). Rather, we use this detailed study to contribute to an understanding of the factors that control progradational and aggradational seismic geometries within carbonate depositional systems. 


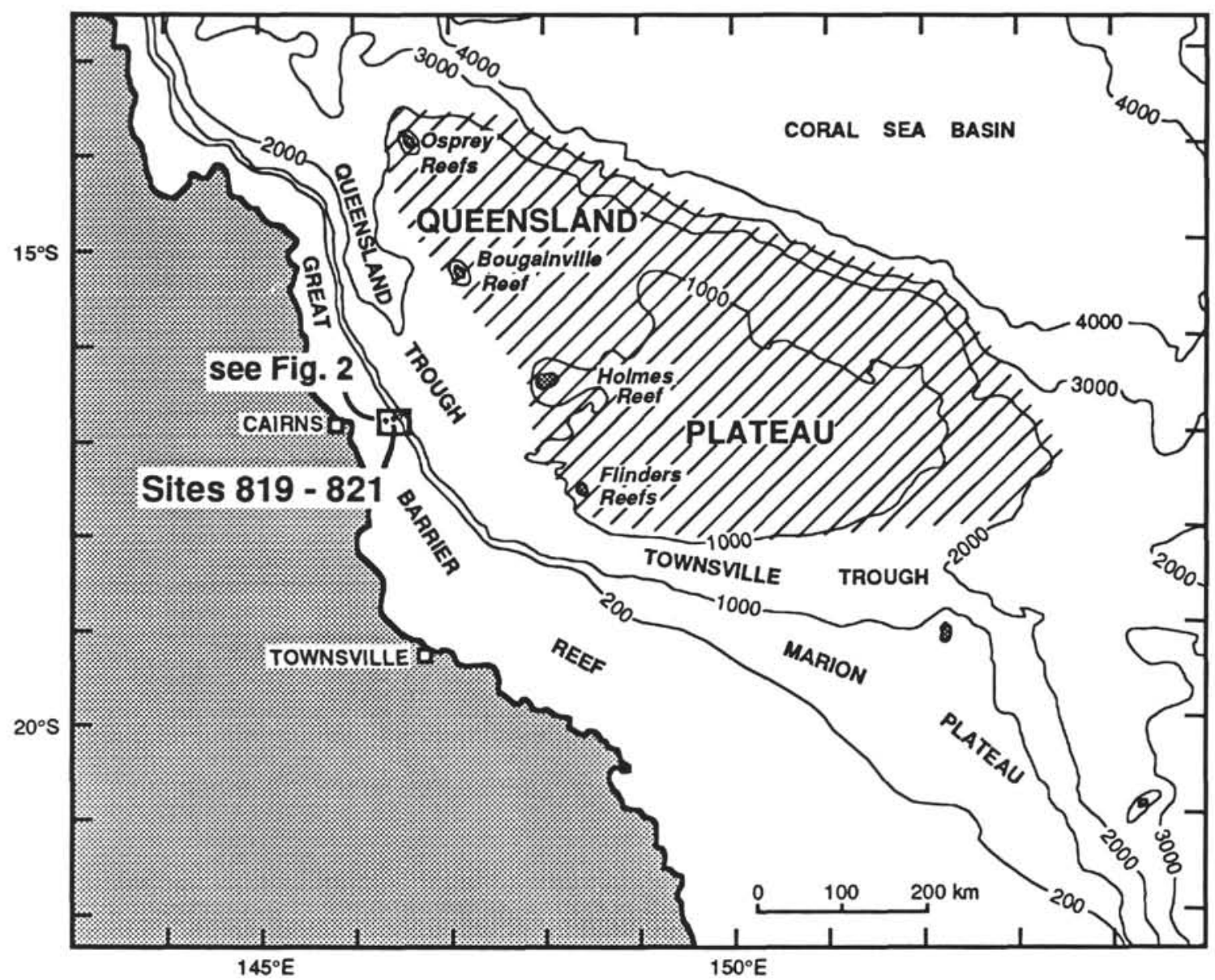

Figure 1. Map showing the major physiographic elements of the northeastern Australian margin, together with the location of Sites 819 to 821 on the central Great Barrier Reef outer shelf. The area shown enlarged in Figure 2 is marked with a box. Bathymetry in meters.

\section{METHODS}

\section{Data Acquisition}

ODP site-survey seismic data were collected by the AGSO in 1987 using the Rig Seismic. With the exception of Line 75/43R (Fig. 2), the seismic source was an 80 -in. ${ }^{3}\left(1311 \mathrm{~cm}^{3}\right)$ SSI- 80 water gun that was towed at a depth of $3 \mathrm{~m}$. Line $75 / 43 \mathrm{R}$ was shot with a $15-$ in $^{3}$ ( 246 $\mathrm{cm}^{3}$ ) SSI-15 water gun in an attempt to obtain higher resolution. Because of the necessity to make tight turns in the vicinity of reefs, only a relatively short $(600 \mathrm{~m})$ streamer could be used. A Teledyne analogue streamer was towed at a $7-\mathrm{m}$ nominal depth at $5 \mathrm{kt}$, with hydrophones in 12.5 (near) and $25 \mathrm{~m}$ (far) groups, to provide 24 data channels and a common depth point (CDP) spacing of $12.5 \mathrm{~m}$. The 2.5 s two-way traveltime (TWT) digital records were filtered with 12 and $256-\mathrm{Hz}$, low- and high-cut filters, respectively. Limited satellite availability meant that at different times the global positioning system (GPS), transit satellites, and dead reckoning were used for navigation; post-cruise processing included using the processed seismic data to optimize ties within the seismic grid.

\section{Data Processing}

The digital seismic data were processed using DISCO software at the AGSO Seismic Processing Center in Canberra. A minimum processing stream was used, that consisted of a 24 -fold stack with a ramped near-trace mute in the lower part of the section to minimize the strong water bottom multiple. Attempts to design spiking deconvolution operators resulted in the loss or degradation of apparently real geologic events; accordingly, no deconvolution was applied. A steep F-K filter was used to remove bands of coherent ship's noise. Because of the short record length, F-K migration used water velocity of $1500 \mathrm{~m} / \mathrm{s}$ throughout the section. No automatic gain control (AGC) was applied to the final output.

\section{Data Interpretation}

Both paper sections and interactive LANDMARK work stations were used to identify and trace sequences; the interactive LANDMARK facilities were particularly useful for tracing sequence boundaries around the numerous loops formed by intersecting lines so that misties could easily be identified and corrected. The interpreted sequence boundaries (see Appendix) were then digitized, and PETROSEIS mapping software was used to produce sequence boundary and isochron maps in two-way traveltime, and isopach maps. Time-todepth conversion used average velocities based on correlation of sequences with cored intervals in the ODP holes (see below).

\section{LITHOFACIES CORRELATION}

Time-to-depth conversions for Sites 819,820 , and 821 utilize continuous records of velocity and density, each extending from the seafloor to within a few meters of the bottom of the hole, based on comparison and merging of core physical-properties data with in-situ log data (Jarrard et al., this volume). The accuracy of the two-way traveltime plot for Site 820 was independently tested with a checkshot survey (Davies, McKenzie, Palmer-Julson, et al., 1991). The 


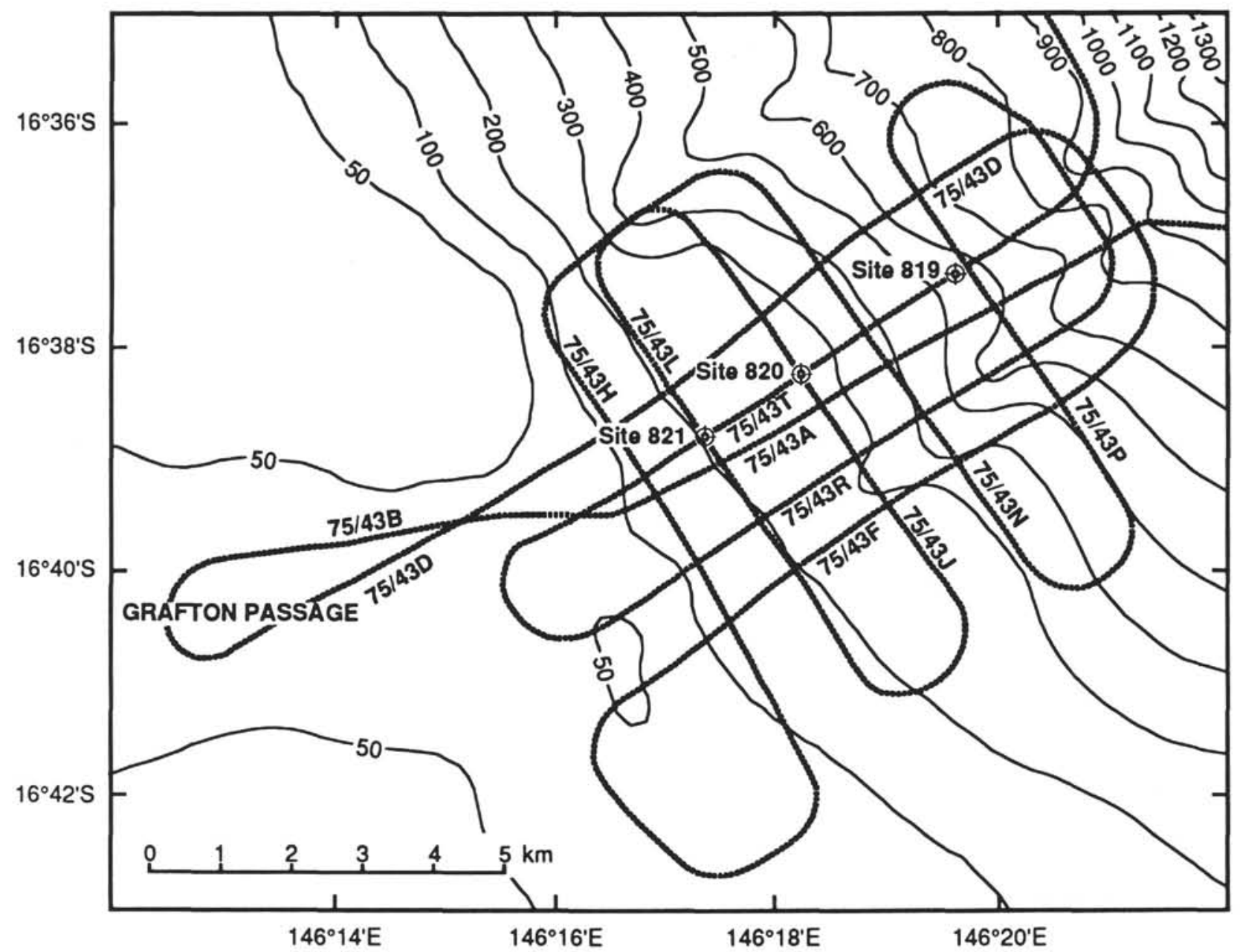

Figure 2. Map showing bathymetry of the central Great Barrier Reef outer shelf and upper slope adjacent to Grafton Passage, together with Sites 819 to 821 and the Rig Seismic site-survey seismic lines. The location of this map is shown in Figure 1. Bathymetry in meters.

two-way seismic traveltime between the shallowest $(93.8$ meters below seafloor [mbsf]) and deepest (334.6 mbsf) check-shots differs from the log-based time by only $1.2 \mathrm{~ms}$, approximately the accuracy of individual check-shots.

We used an estimate of the Rig Seismic wavelet for the generation of our synthetics. As the source signature of the 80 -in. ${ }^{3}$ water gun had not been directly measured, we obtained an estimate by examining all site-survey seismic profiles and then selecting and averaging "clean" seafloor reflections from several regions. These reflections were chosen on the basis that they had a consistent form over many traces. We minimized biasing interference from shallow reflectors by selecting seafloor reflector patterns that persisted over widely spaced areas, in spite of different lithologies and sedimentation rates. Synthetic seismograms were calculated using a one-dimensional convolution model, in which the derived water-gun wavelet was convolved with an impedance log (velocity times density) and sampled at a spacing of $2 \mathrm{~ms}$ as a function of log-based two-way traveltime. This convolution model includes primaries plus interbed multiples, but it does not include seafloor/sea-surface multiples; the latter are present in seismic sections within the succession drilled by the Great Barrier Reef margin holes. Amplitudes of synthetic seismograms have been scaled so that the largest peak on each has the same height.

Comparison of the synthetic seismograms with the seismic data (Fig. 4) shows that there is excellent correlation for Sites 820 and 821 , but only poor correlation at Site 819 . The high-amplitude reflectors at 525 and $558 \mathrm{~ms}$ (TWT) at Site 821 and at 593,612, and $634 \mathrm{~ms}$ (TWT) at Site 820 match high-amplitude peaks on the synthetics to provide a high degree of confidence regarding the seismic-lithofacies correlations at these sites. The poor correlation at Site 819 is probably at least partly a result of drilling slightly off the seismic line on a steep slope, with Site 819 lying about $40 \mathrm{~m}$ deeper than the equivalent position on Line 75/43T.

The excellent synthetic correlation at Site 820 , together with the detailed sedimentological descriptions available (Feary and Jarrard, this volume; Peerdeman et al., this volume) and its position farther away from the effects of the multiple compared with Site 821, means that this site provides an excellent basis for correlating lithofacies with particular seismic sequences (see below). The lithofacies logs from Sites 819 and 821 (Davies, McKenzie, Palmer-Julson, et al., 1991) are used as additional data sources.

\section{BIOSTRATIGRAPHIC CORRELATION}

Shipboard (Davies, McKenzie, Palmer-Julson, et al., 1991) and post-cruise (Wei and Gartner, this volume) nannofossil studies provide a relatively coarse biostratigraphy for the sequences intersected at Sites 819,820, and 821. The Calcidiscus tropicus FAD (first appearance datum) at $1.48 \mathrm{Ma}$ was not reached in any of these sites, with the result that only six datums (Emiliania huxleyi Acme, 0.085 $\mathrm{Ma}$; Emiliania huxleyi LAD [last appearance datum], $0.275 \mathrm{Ma}$; Pseudoemiliania lacunosa FAD, $0.465 \mathrm{Ma}$; small Gephyrocapsa Acme, $0.93 \mathrm{Ma}$; Gephyrocapsa spp. A-B FAD, $1.10 \mathrm{Ma}$; and Helicosphaera selli FAD, 1.27 Ma) occur within the drilled successions. In addition, it is difficult to locate the Helicosphaera selli datum 


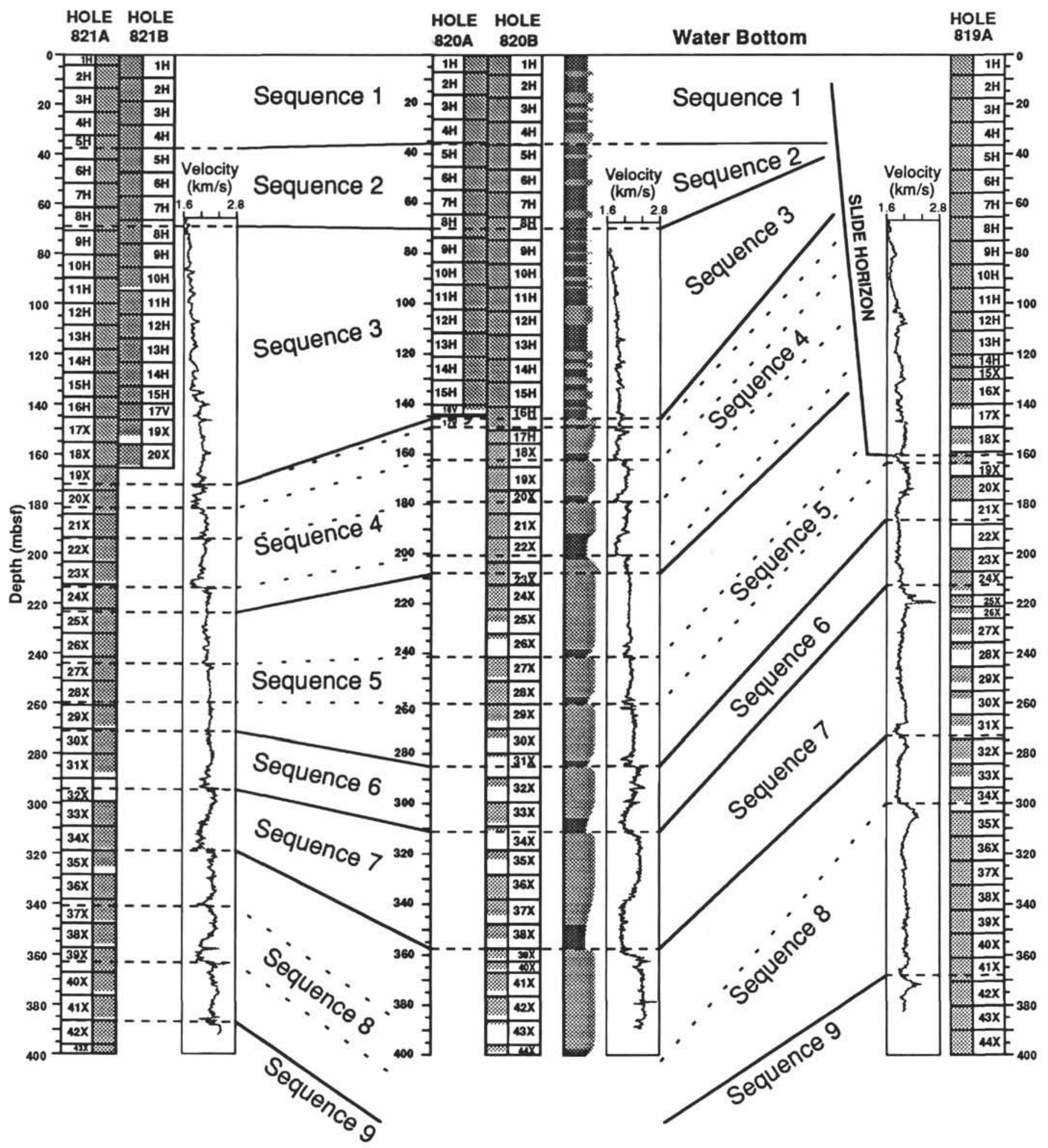

Figure 3. Correlation of seismic sequences with coring at Sites 819 to 821 . Solid correlation lines mark sequence boundaries, whereas dashed lines indicate individual cycle correlations. Stippled blocks indicate core recovery. Velocity downhole logs for each hole are presented because they show the precise location of most sequence boundaries in zones of poor core recovery. The schematic lithofacies log for Site 820 is from Feary and Jarrard (this volume). 


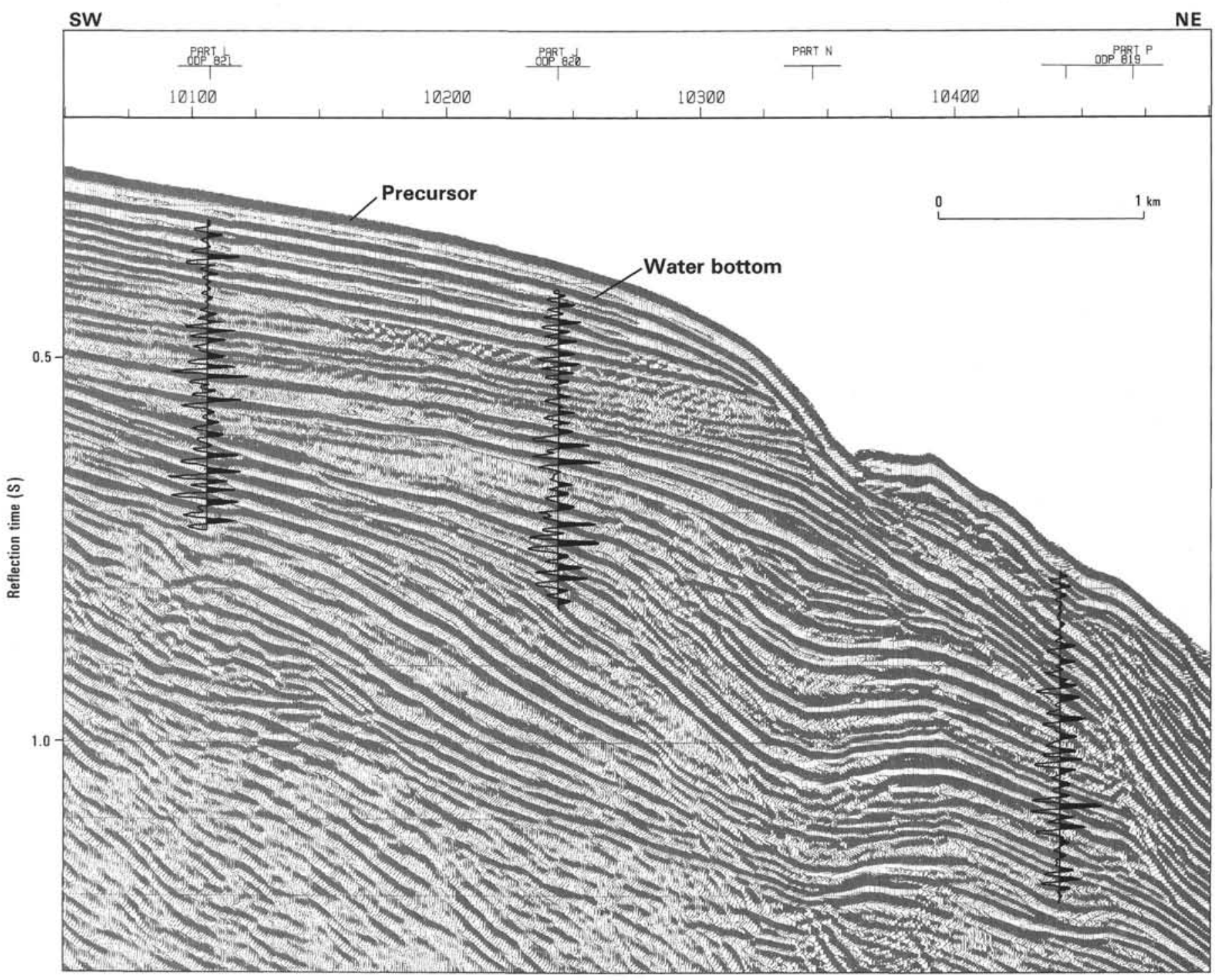

$23 / 00 / 300$

Figure 4. Seismic data through Sites 819 to 821 (Line 75/43T), showing correlation of synthetic seismograms with seismic reflectors at each site. Note that there is excellent correlation at Sites 820 and 821; correlation is only moderate at Site 819, probably as a result of hole location slightly off the seismic line.

precisely, as this species is extremely rare (Wei and Gartner, this volume). The correlation of biostratigraphic datums with seismic sequences (Fig. 5) shows that excellent agreement exists at virtually all levels; the slight discrepancies at the 0.93- and 1.27-Ma levels can be attributed to poor core recovery and index species rarity.

\section{SEISMIC STRATIGRAPHY}

The manner in which seismic sequences are delineated is highly scale-dependant, as data used for seismic stratigraphic analysis range from very high-resolution (meter or less), shallow-penetration boomer datasets (e.g., Brooks and Holmes, 1989; Saito, 1991) to the more common, low-resolution (tens of meters), deep-penetration, low frequency air-gun data sets (e.g., McGovney and Radovich, 1985; Erlich et al., 1990). The water-gun data used in the ODPLeg 133 site-surveys (Feary et al., 1990) is intermediate between these extremes, with good penetration to 2 to $2.5 \mathrm{~s}$ (TWT) and a relatively broad frequency bandwidth so that reflectors in the upper part of the succession represent as little as 8 to $10 \mathrm{~m}$. The scale of the seismic sequence interpretation presented here is at the uppermost limit possible with this type of data, with 9 sequences (Fig. 3, Table 1) identified within the top 400 to $420 \mathrm{~m}$ of the sedimentary succession (which corresponds to the interval intersected at Sites 819 to 821 ). It is likely that condensed sequences are much thinner than a single reflector, so one must be cautious when interpreting unconformities; where reflectors coalesce, it is possible that they may represent either an erosional unconformity or a condensed sequence.

Because of the need to use a short streamer, it was not possible to substantially attenuate the multiple during data processing. As a consequence, considerable difficulty exists when tracing and correlating sequences and categorizing seismic facies characteristics within the shallower water part of the section, particularly in the vicinity of Site 821 and farther landward toward the present Great Barrier Reef. In addition, the relatively steep bathymetry and similarly steeply-dipping reflectors on the upper slope have resulted in offside or sideswipe reflectors that, in some cases, are sufficiently strong to interfere significantly with on-line reflectors.

In overview, the sequences show three types of seismic geometry: sigmoidal, oblique, prograding sequences in the lower part of the section; purely aggradational outer shelf sequences at the top of the section; separated by an intermediate sequence having both progradational and aggradational characteristics (Fig. 6). The following analysis is based on the division of the sedimentary section down to the maximum ODP penetration into discrete depositional sequences (sum- 


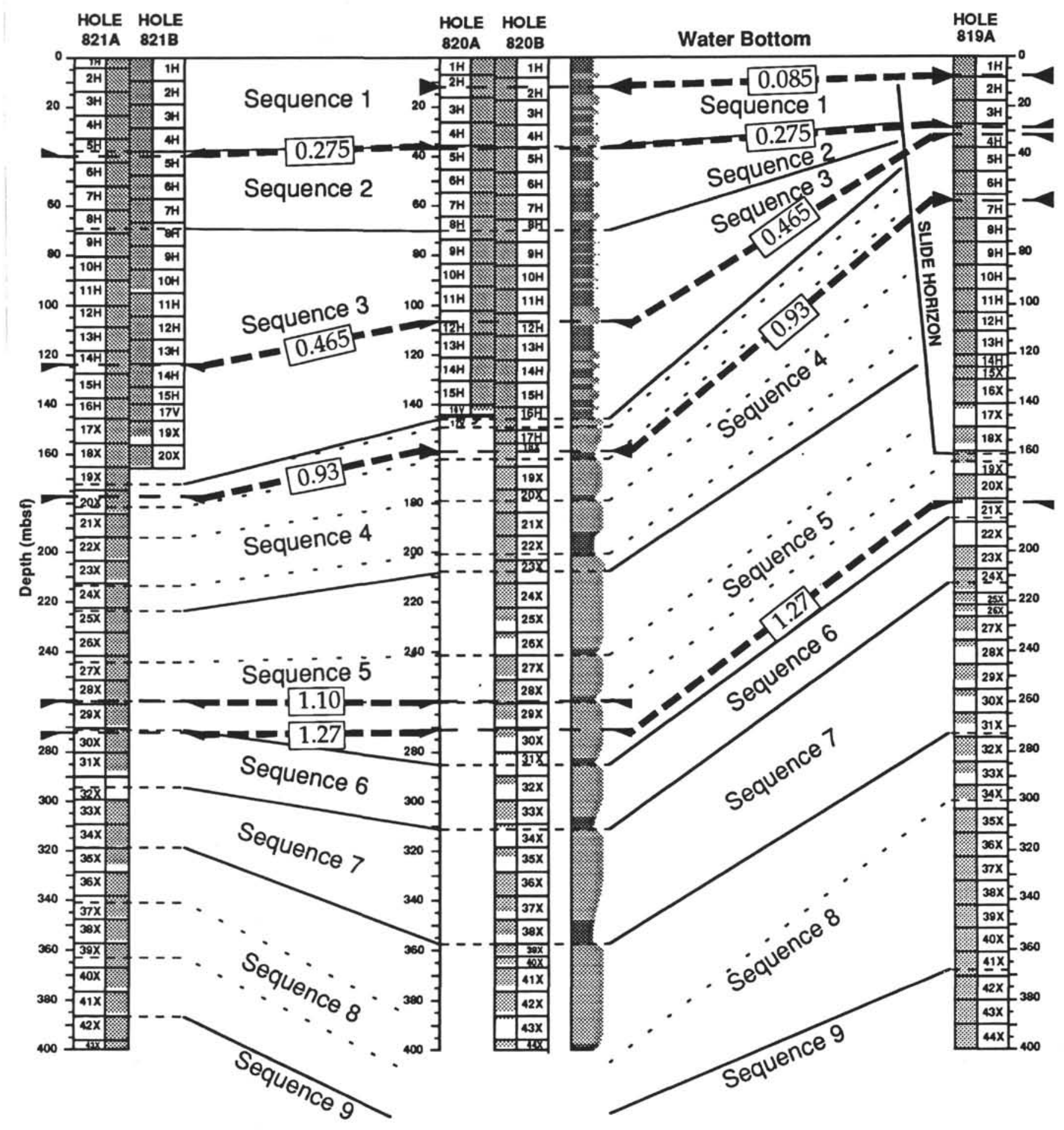

Figure 5. Correlation of seismic sequences with nannofossil biostratigraphic datums (shown by heavy dashed lines) for Sites 819 to 821 . Nannofossil data are after Wei and Gartner (this volume).

marized in Table 1), mostly bounded by unconformities (c.f. Mitchum et al., 1977). Tracing of sequence boundaries and individual reflectors throughout the seismic grid beneath the present-day outer shelf is generally excellent, except in areas where interference by the multiple is a problem. However correlation onto the upper slope is only possible where dislocation planes, which appear to relate to multiple generations of slumps, are not present. These dislocation surfaces only affect the shallowest part of the upper slope succession in the southeastern part of the grid (e.g., Line 75/43F, see Appendix), but penetrate progressively deeper into the section to the north to the extent that a severe dislocation of most of the upper slope section occurs in Line $75 / 43 \mathrm{D}$. As a result, we were able to correlate only the lower part of Sequence 5 and Sequences 6 to 9 with drilling results at Site 819 (Fig. 3).

Small mounds occur beneath the present day outer shelf on many sections (e.g., Line 75/43D, see Appendix), primarily within the 
Table 1. Chart summarizing the characteristics of each of the seismic sequences intersected at Sites 819 to 821 .

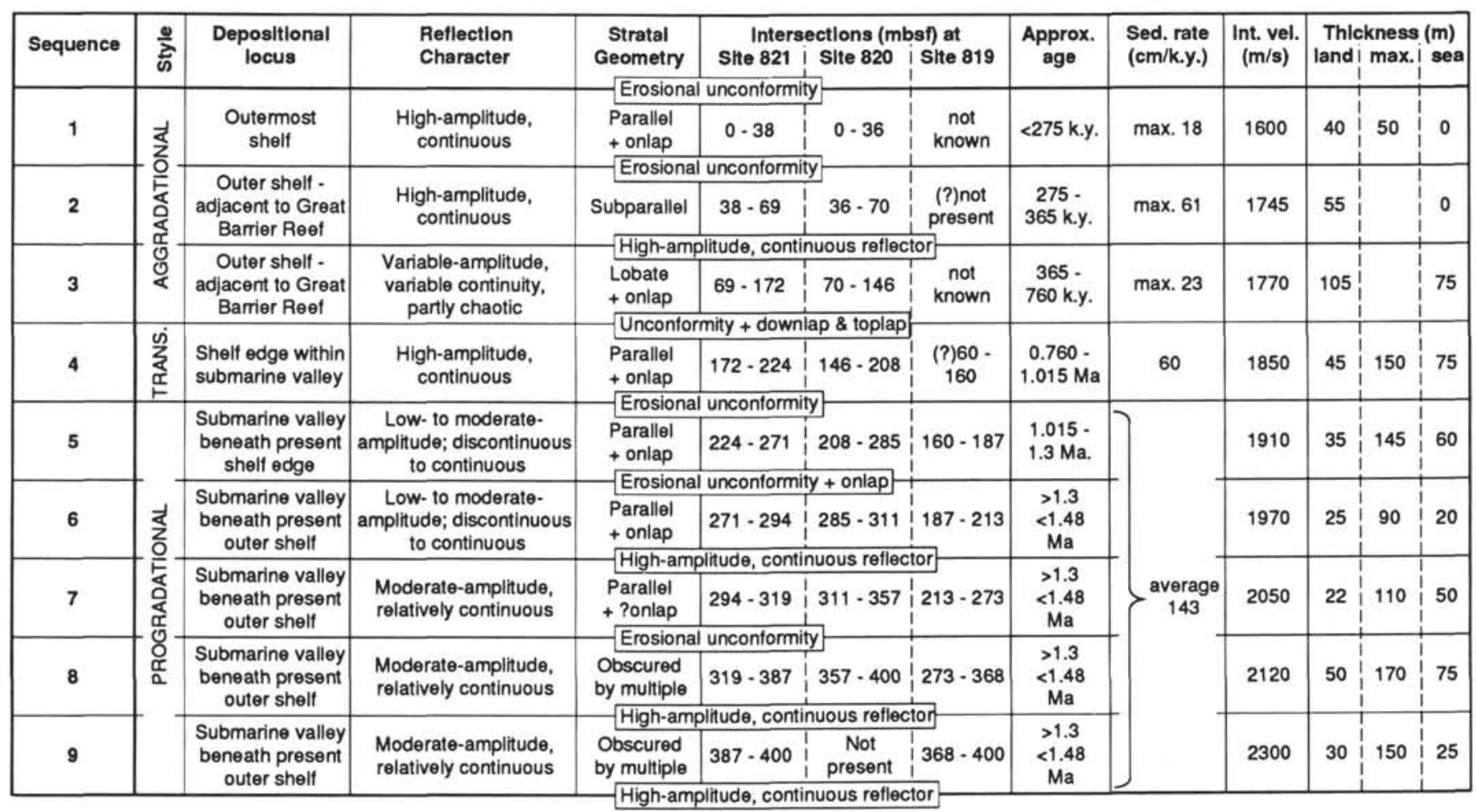

middle part of the succession (Sequences 3 to 6). These have been interpreted as small reefal buildups, with typical lateral extents of 120 to $150 \mathrm{~m}$ and apparent relief ranging from approximately 7 to $20 \mathrm{~m}$. Because of the combined effects of differential compaction around the mounds and velocity pull-up beneath the mounds, we were not always able to determine which horizons contained mounds, and which merely mirrored underlying or overlying mounds. However, where mound reflectors penetrate "through" overlying reflectors they are definitely present.

The terms used here to describe overall stratal patterns are mostly those in general use, as defined by Mitchum et al. (1977) and Mitchum (1977). In addition, the terms used to describe stratal relationships within sequences follow Doglioni et al. (1990). However in some

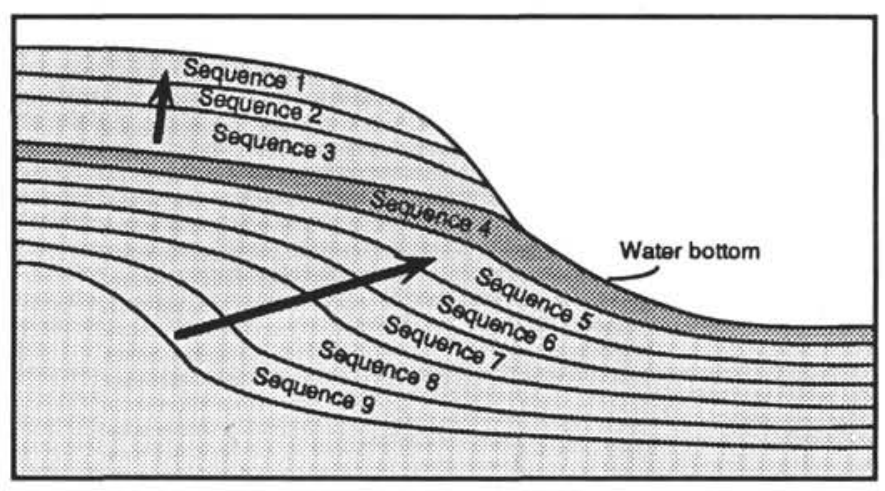

Figure 6. Schematic illustration of purely aggradational (Sequences 1 to 3), transitional aggradational/progradational (Sequence 4), and obliquely progradational (Sequences 5 to 9) seismic geometries observed on the outer shelf and upper slope adjacent to the central Great Barrier Reef. Arrows indicate directions of aggradation and progradation. Sequence 4 has a more progradational geometry within broad submarine valleys and a more aggradational geometry on the promontories between valleys. cases "sequence boundary" has been used rather loosely. Strictly, this term should only be applied where regional unconformity or correlative conformity can be demonstrated (Mitchum, 1977); however, within the small area dealt with here it was necessary to use several apparently conformable, high amplitude reflectors traceable over most of the seismic grid as sequence boundaries in order to illustrate the geometry of sedimentary packages.

The depositional sequence boundaries described here display considerable variation in geomorphic shape. The base of Sequence 9 (Fig. $7 \mathrm{~J})$ is characterized by broad submarine valleys separated by narrower promontories (see below). By contrast, the present-day bathymetry shows that slightly more than half of the area covered by the seismic grid consists of a broad, gently-sloping outer shelf that passes over the shelf edge at a depth of 275 to $325 \mathrm{~m}$ into an upper slope having steep-walled canyon or valley heads (Fig. 7A). The shapes of the major depositional packages making up the outermost shelf/upper slope provide a record of the transition between these surfaces; i.e., Sequences 5 to 9 record the progradational filling in of the broad valleys (Figs. 8B, 8C); Sequence 4 both fills in valley remnants and drapes the bathymetric surface (Fig. 8A); and Sequences 1 to 3 reflect the accumulation of a seaward-thinning shelf wedge. This sequential transition is well illustrated by comparison of contoured maps of each sequence boundary (Fig. 7). In addition, isopach maps are particularly useful for showing the geometry of the obliquely progradational sequences (Fig. 9), although they provide poor representations of the geometry of the aggradational sequences primarily because of the effects of canyonforming erosion on already thin sequences.

\section{Aggradational Package (Sequences 1 to 3)}

\section{Sequence 1}

The uppermost seismic depositional sequence can be recognized only on the outer shelf, although the slumped region on the upper slope precludes tracing of the sequence beyond the shelf edge. The sequence thins both toward the reef and seaward toward the shelf edge, so that the depositional locus lies on the outermost shelf. The 


\section{A. Bathymetry (m)}

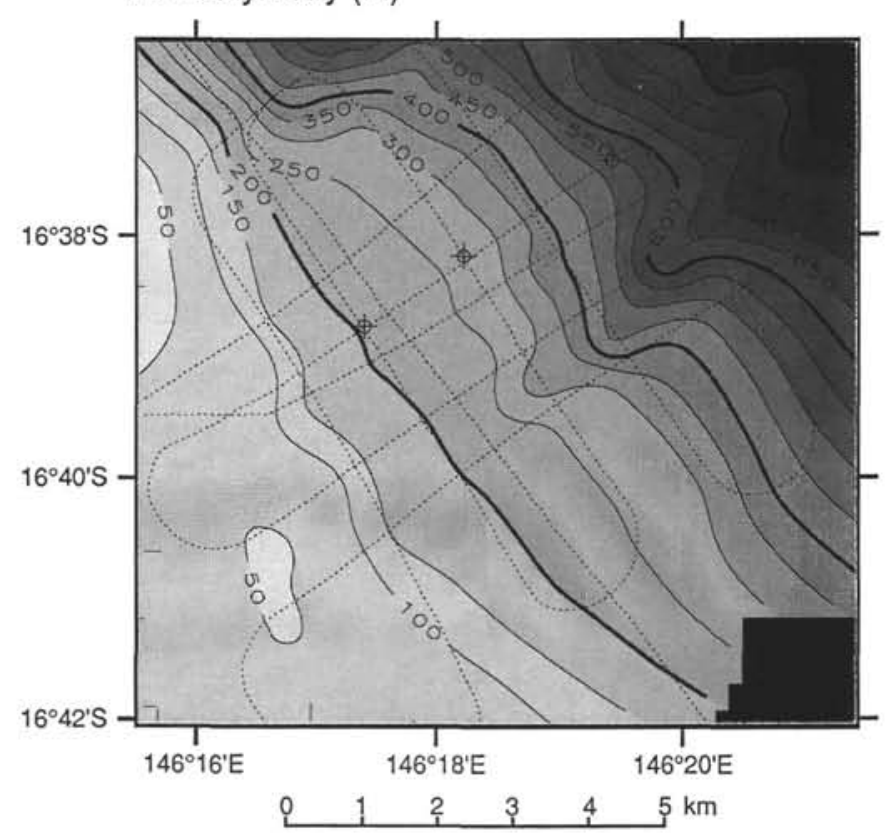

\section{Depth to base Sequence 2}

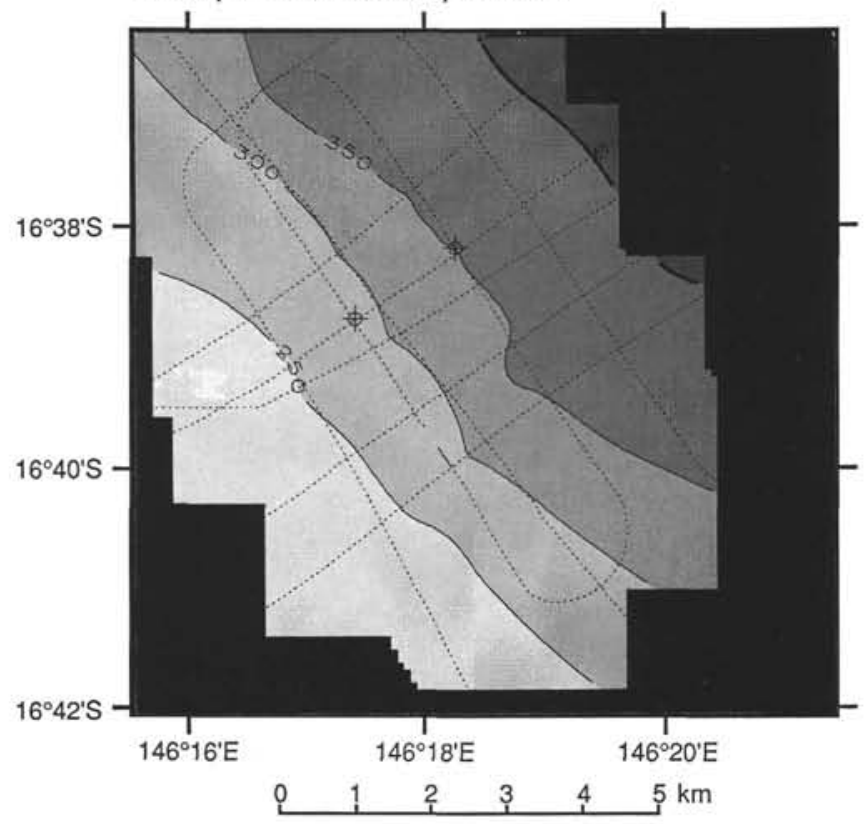

\section{B. Depth to base Sequence 1}

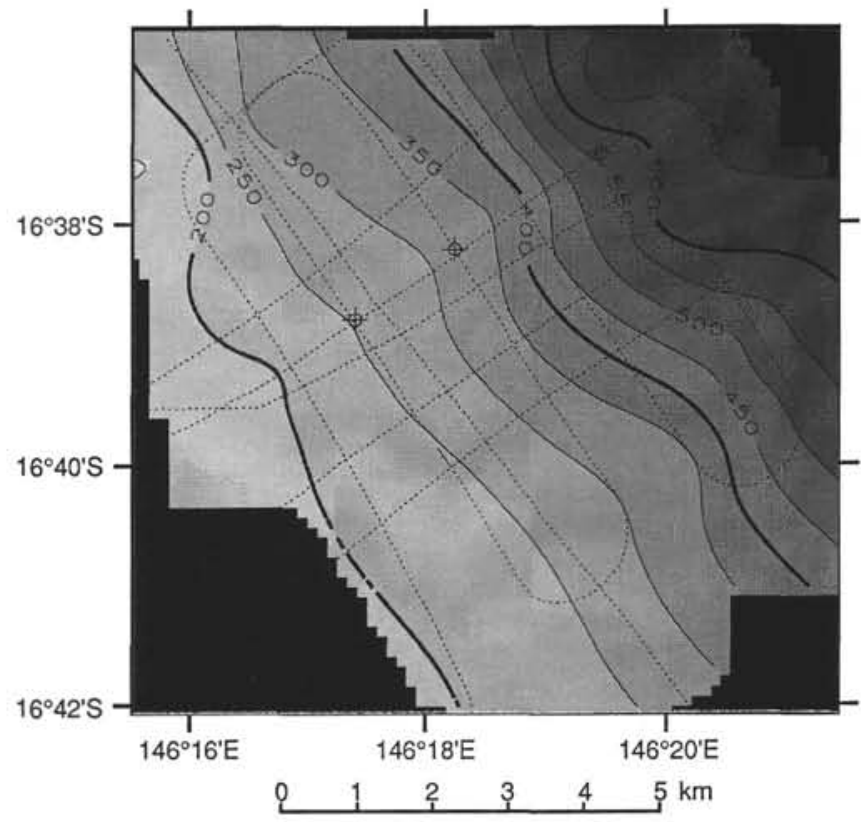

D. Depth to base Sequence 3

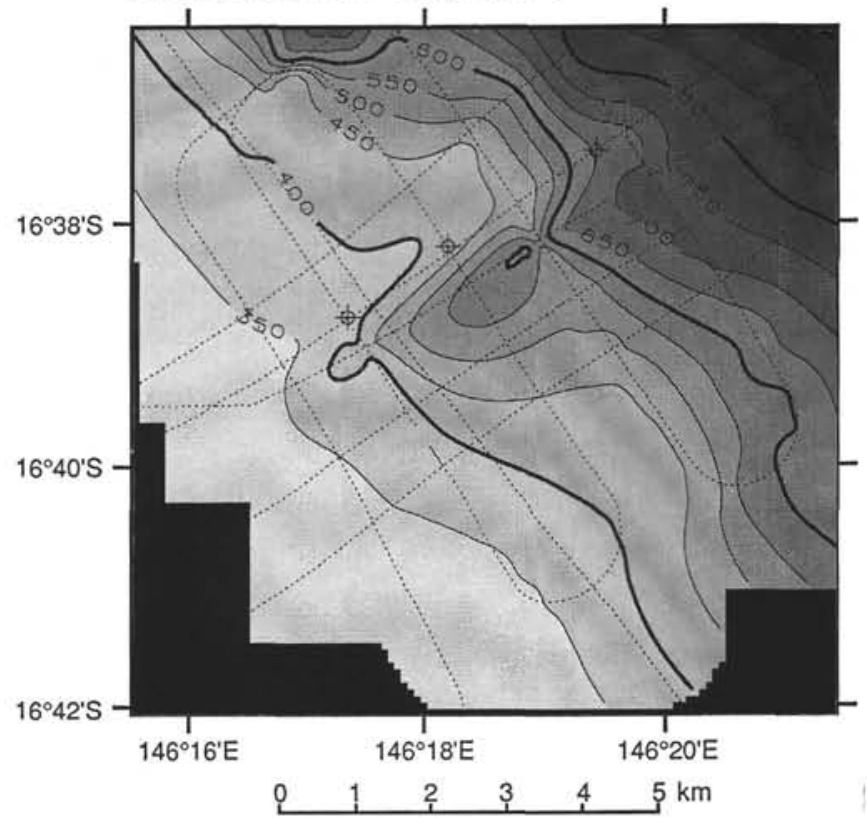

Figure 7. Maps showing present-day bathymetry (A) and depth to sequence boundaries (B to J) for each seismic sequence. All contours are in meters below sea-level.

sequence boundary at the base of Sequence 1 is a clear erosional unconformity, truncating underlying reflectors, and, in turn, similarly unambiguous truncation of Sequence 1 reflectors occurs at or close to the present-day water bottom. Small, steep-walled canyons visible on strike lines (e.g., Lines 75/43P, 75/43N) reflect relatively recent erosion. The limits of seismic resolution prevent any precise age determination for this erosive event; however, because these canyons cut deeply into Sequence 1 they must represent erosion within the last 80 k.y. Sequence 1 is composed of two similar subsequences of approximately equal thickness, separated by a continuous, highamplitude reflector. Each subsequence contains reflectors that onlap onto the underlying subsequence base (Fig. 10). This onlapping geometry indicates that the base of each subsequence marks a relative fall in depositional base-level (Vail et al., 1977a; Christie-Blick, 1991), followed by a rise to form the onlap.

Lithofacies correlation with Site 820 shows that the reflectors at the base of each subsequence correspond to thick (4-5 m), lighter-colored, more calcareous, coarse, bioclastic wackestone bands, with the onlapping reflectors within each subsequence corresponding to much thinner $(0.7-1.5 \mathrm{~m})$, light-colored, coarse, bioclastic wackestone bands (Feary and Jarrard, this volume). Biostratigraphic correlation with Sites 820 and 821 shows that Sequence 1 was deposited entirely within the past $275 \mathrm{k} . \mathrm{y}$. (Wei and Gartner, this volume) and that the base of the upper subsequence was deposited between 80 and 275 k.y. (Fig. 5). Biostratigraphy also shows that the uppermost $29 \mathrm{~m}$ at Site 819 correlates with Sequence 1; however the combined effects of slumping 


\section{E. Depth to base Sequence 4}

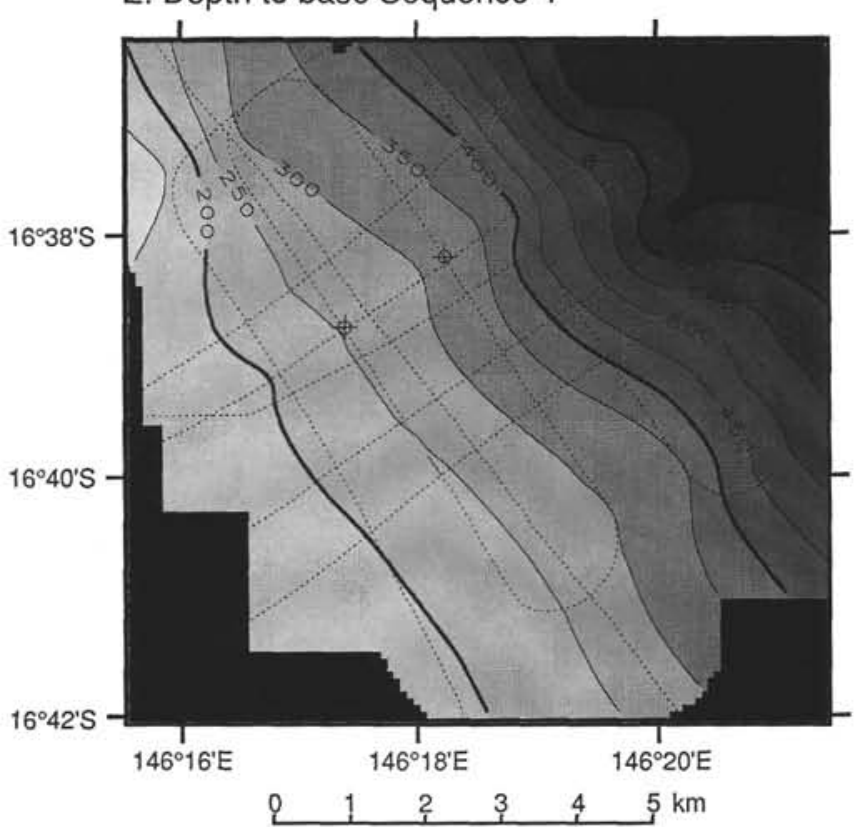

\section{G. Depth to base Sequence 6}

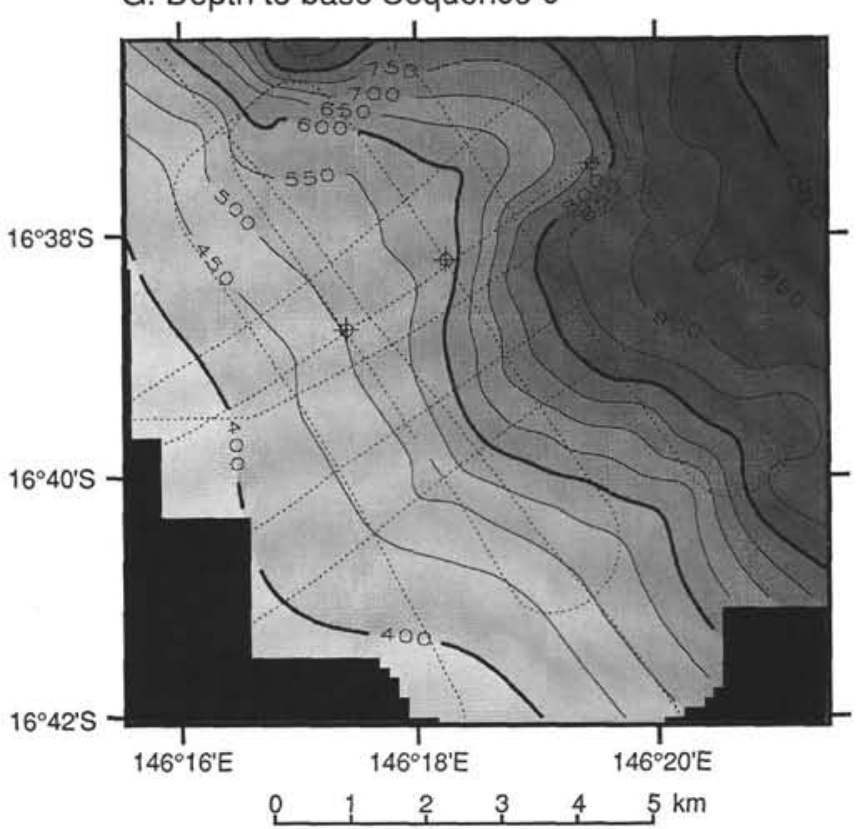

Figure 7 (continued).

and late Holocene canyon-forming erosion prevented our tracing of the Sequence 1 boundaries into the area of Site 819 .

\section{Sequence 2}

Sequence 2 is thickest at the landward edge of the seismic grid, near the Great Barrier Reef. It thins seaward, and disappears at the shelf edge. It is impossible to determine how much of this thinning is a result of erosional truncation by the reflector marking the base of Sequence 1, and how much reflects variation in the original depositional thickness; it is likely that both are applicable. Sequence 2 is also slightly thicker between submarine valleys and thins gradually toward the submarine valley axes. The basal sequence boundary is a continu-

\section{F. Depth to base Sequence 5}

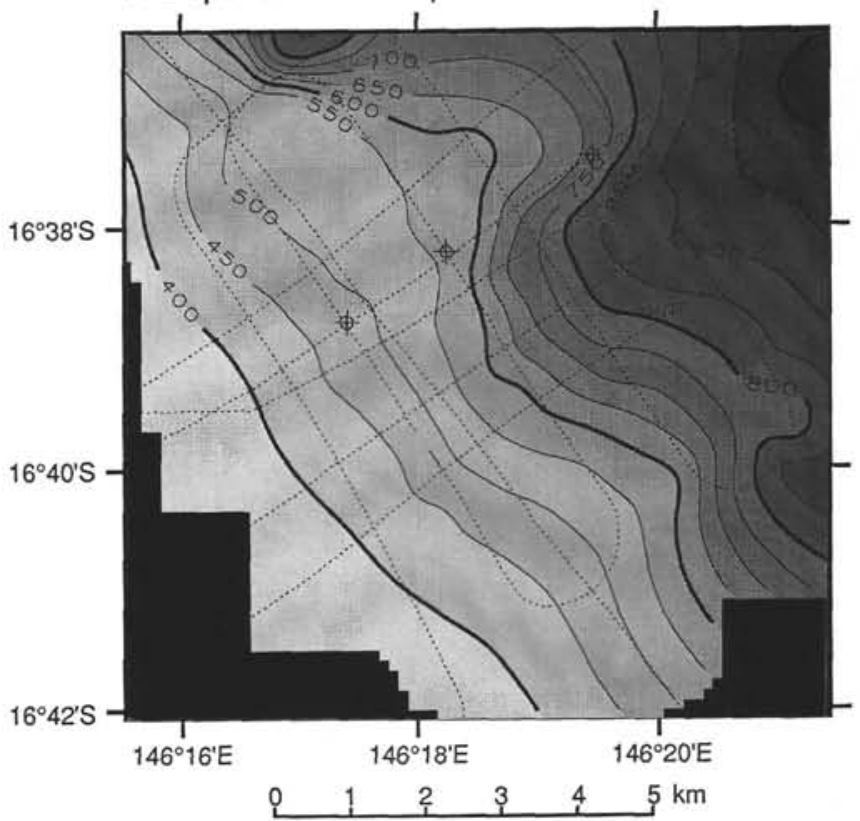

H. Depth to base Sequence 7

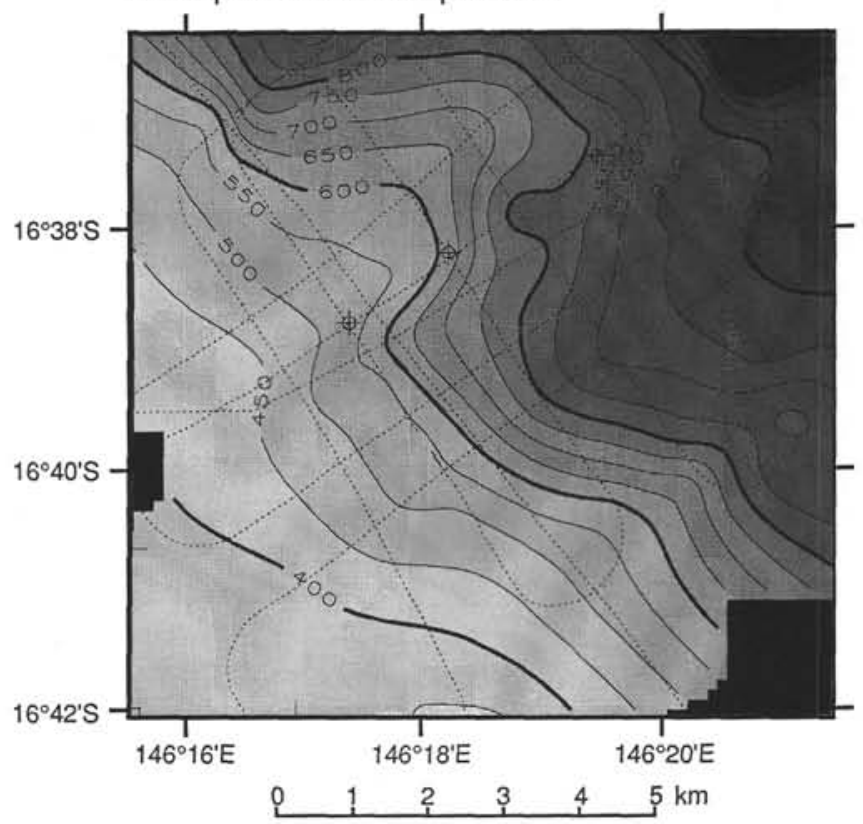

ous, high-amplitude reflector that separates the continuous, subparallel reflectors of Sequence 2 from the discontinuous reflectors of Sequence 3. Because of the lack of continuity of Sequence 3 reflectors, it is not possible to determine with certainty whether this boundary is an offlap surface (Christie-Blick, 1991); nevertheless this boundary marks a major change in reflector style. A relatively large reefal mound is present at the top of Sequence 2 near the southwestern edge of the seismic grid (Line 75/43F; CDPs 3555-3585), adjacent to the Great Barrier Reef. This mound is approximately $350 \mathrm{~m}$ wide at the base and has an estimated relief of $25 \mathrm{~m}$.

Although slumping prevented our tracing of these sequence boundaries to Site 819 , biostratigraphy (Fig. 5) indicates that the sequence is either very highly condensed or, more probably, missing entirely. The 


\section{Depth to base Sequence 8}

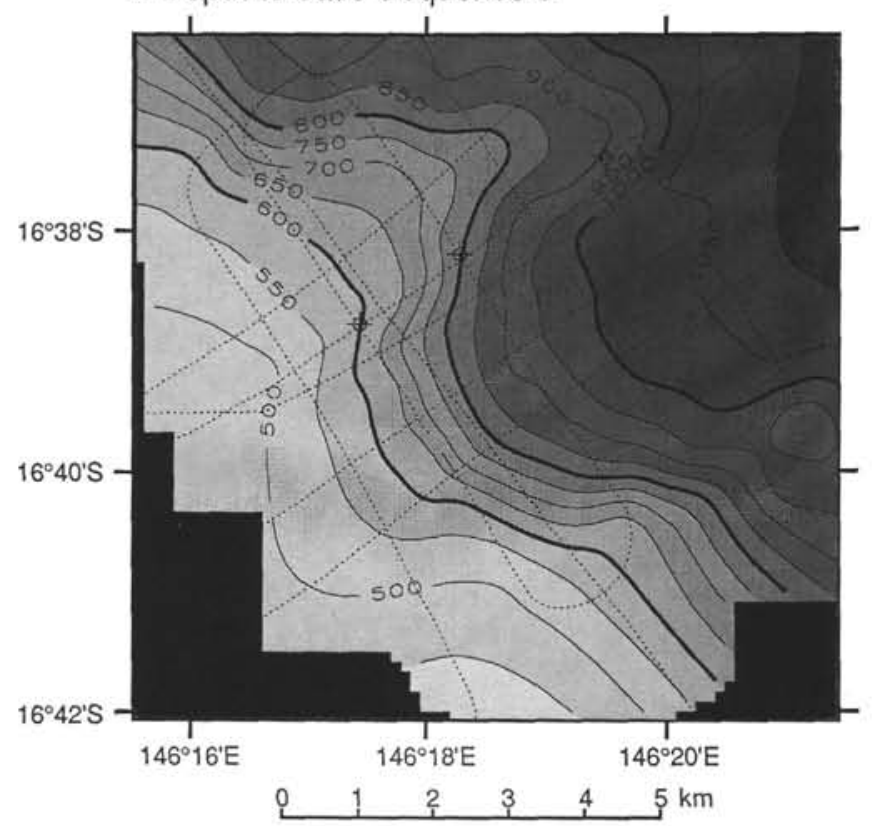

Figure 7 (continued).

lithofacies intersected in this interval at Site 820 (Feary and Jarrard, this volume) consist of dark greenish-gray, terrigenous clay-rich, variably calcareous mud, with three interbedded thin (1-3 m), lighter green, more calcareous, bioclastic wackestone beds. Carbonate content increases upward within each muddy bed. The lower two wackestone beds have produced continuous, high-amplitude, subparallel seismic reflectors; the thinner $(1 \mathrm{~m})$, uppermost bed appears to be below seismic resolution. The age of Sequence 2 is not well constrained by biostratigraphic data (Fig. 5); the sequence top occurs immediately above the 275 k.y. nannofossil datum, but the base occurs midway between the 275 and 465 k.y. datums (Wei and Gartner, this volume). Assuming a broadly constant sedimentation rate, the age of this basal sequence boundary is likely to be close to 365 k.y.

\section{Sequence 3}

Sequence 3 is the thickest and seismically most complex of all the sequences, representing the interaction of multiple depositional processes. The sequence occurs dominantly as an aggrading shelf sequence, thickest $(105 \mathrm{~m}$ ) landward near the present Great Barrier Reef and thins gradually over the outer shelf to the shelf edge. It is also present on the uppermost slope; however, a combination of Holocene erosion and extensive upper-slope slumping prevents any appreciation of its thickness or extent in this area. Sequence 3 reflector character varies considerably over the seismic grid. On the upper slope, where the lower part of the sequence can be identified below slump effects (Lines 75/43F, 75/43P), it occurs as continuous, broadly subparallel reflectors. By contrast, the shelf sequence includes continuous and discontinuous, high- and low-amplitude, and subparallel and divergent reflectors. A "chattery" zone, characterized by discontinuous, apparently chaotic reflectors with markedly divergent attitudes, occurs toward the top of this sequence on the outermost shelf in all dip sections (see Appendix). There are indications that this chattery zone may represent small channels that are below the limit of seismic resolution. Both upper and lower sequence boundaries on the shelf are marked by changes from the continuous, relatively high amplitude reflectors of Sequences 2 and 4 to the complex, discontinuous reflector pattern of Sequence 3 . The sequence boundary at the base of Sequence 3 is an offlap surface (Christie-Blick, 1991), with

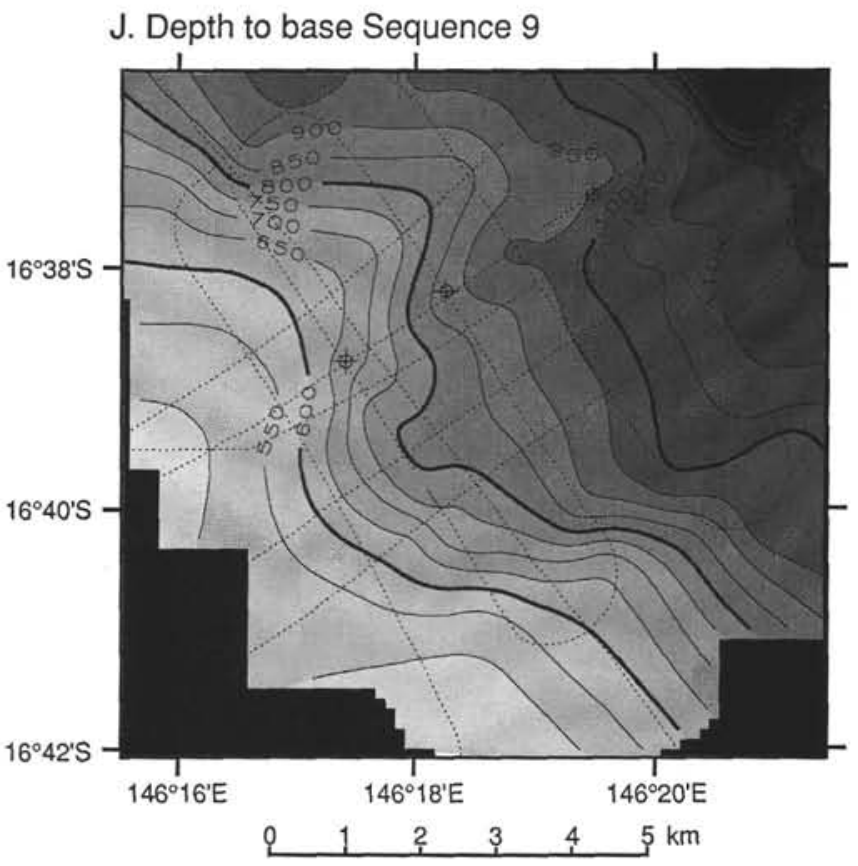

downlap of Sequence 3 reflectors onto this surface on the uppermost slope (Line $75 / 43 \mathrm{~N}$ ) and apparent toplap in the uppermost part of Sequence 4 near the shelf edge. However, it is unclear whether the unconformity represents erosion or simply a non-depositional or bypass hiatus surface. Small reefal mounds occur on a number of seismic sections (e.g., Lines 75/43D; 75/43F; 75/43L), predominantly low in the sequence and toward the landward margin of the grid.

The geometry and character of Sequence 3 reflectors on the outer shelf indicate that a complex arrangement of sediment lobes that extend seaward from the landward edge of the seismic grid have been onlapped by subparallel reflectors (shown schematically in Fig. 11). These lobes are characterized by irregular outlines that either lack or have very low-amplitude internal reflectors. In some cases, lobes have been superimposed (e.g., Line 75/43L; CDPs 6000-6100). Although the seismic grid is insufficiently detailed to define precisely the geometry of these sediment lobes, it appears that they are uniformly thin (up to 20-25 m), but have wide lateral extents (up to 2-3 km). These lobes are less abundant and thinner away from the southwestern edge of the seismic grid and appear to be derived from that direction. However, there are indications that another, more distant, source from the northwest also may have existed.

The stratal complexity does not appear to be matched by lithofacies complexity at Sites 820 and 821 , which predominantly consist of greenish-gray, clayey wackestones with interbedded bioclastic packstone beds. However, unusual wackestone beds present at both sites that contain a coarse, shallow-shelf, bioclastic assemblage of Halimeda flakes and coral, bryozoan, and molluscan debris (Davies, McKenzie, PalmerJulson, et al., 1991; Feary and Jarrard, this volume) may represent the sediment lobes. The lithofacies at Site 820 corresponding to the top of Sequence 3 provide no explanation for the distinctive chattery zone present on the seismic sections. Again the resolution of biostratigraphic data is too low to determine precisely the age range of Sequence 3 (Fig. 5), with the $465 \mathrm{k} . \mathrm{y}$. nannofossil datum occurring near the middle of the sequence and the 930 k.y. datum occurring within the underlying sequence (Wei and Gartner, this volume). Assuming broadly constant sedimentation rates, it is likely that Sequence 3 was deposited during the interval from approximately 365 to 760 k.y. Biostratigraphic correlation with Site 819 confirms that the top part of Sequence 3 is missing and that the lower part probably is present from 33 to approximately 60 mbsf. 
A. Isopach map for Sequence $4(\mathrm{~m})$

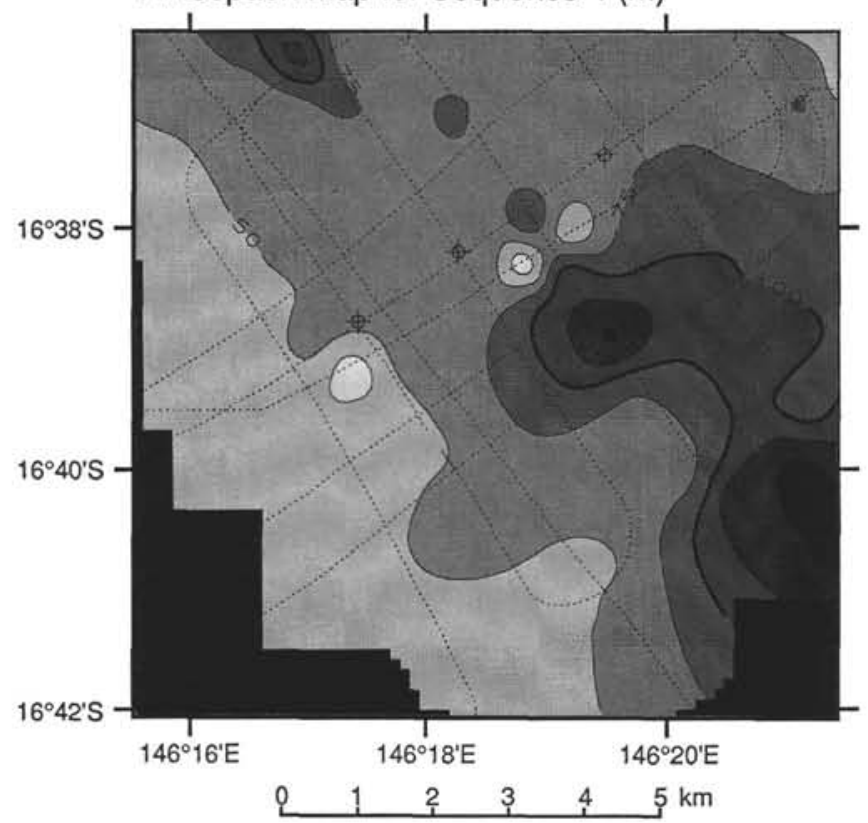

B. Isopach map for Sequences 5 and $6(\mathrm{~m})$

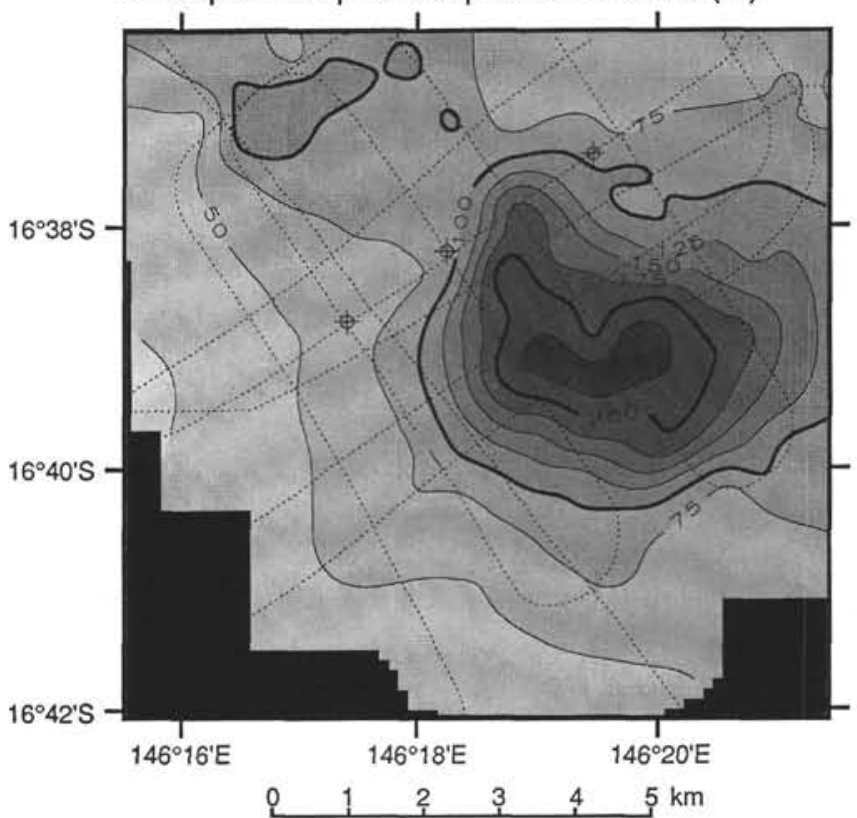

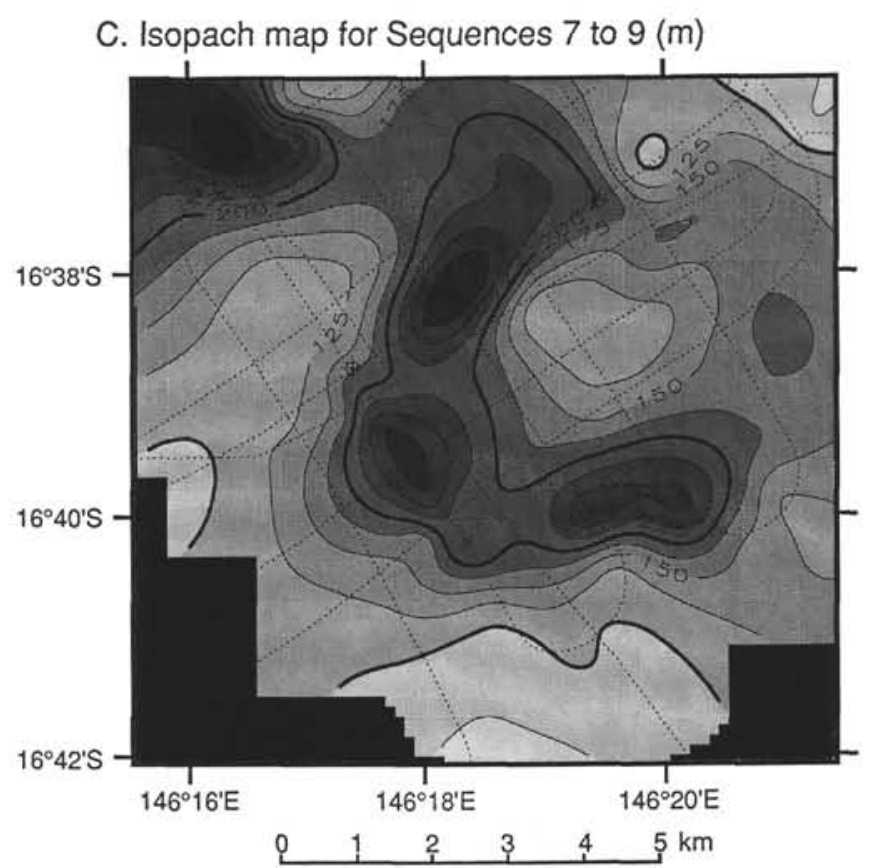

Figure 8. Isopach maps for Sequence 4 (A); Sequences 5-6 (B), and Sequences 7-9 (C); all contours are in meters.

\section{Aggradational/Progradational Package}

\section{Sequence 4}

Sequence 4 is characterized by relatively continuous, subparallel, high amplitude reflectors. The sequence is present over the entire seismic grid with only minor variation, except where the upper reaches of late Holocene canyons have removed part of the sequence. This sequence is thickest at the shelf edge, gradually thinning both landward towards the reef and seaward down the upper slope (Fig. $8 \mathrm{~A})$. The thickness variation at the shelf edge reflects variations in paleobathymetry at the basal sequence boundary, with the thickest parts of the sequence filling in original depressions that correspond to the upper parts of broad submarine valleys (e.g., Line $75 / 43 \mathrm{~N}$ ). As a consequence, seismic dip lines that cross these broad valley areas show a pronounced sigmoidal oblique progradational geometry (e.g., Line $75 / 43 \mathrm{~F}$ ), whereas those crossing between valleys show a more uniform aggradational geometry (e.g., Line 75/43A). The sequence boundary at the base of Sequence 4 is a pronounced erosional unconformity. Reflectors at the base of the sequence are of uniform thickness over the entire seismic grid, with the thickening at the shelf edge being caused by reflectors that thin landward and onlap lower reflectors. Downslope, these reflectors appear to thin and coalesce with underlying reflectors, although slumping obscures stratal relationships over much of the grid. The sequence boundary at the top of 


\section{A. Isopach map for Sequence $5(\mathrm{~m})$}

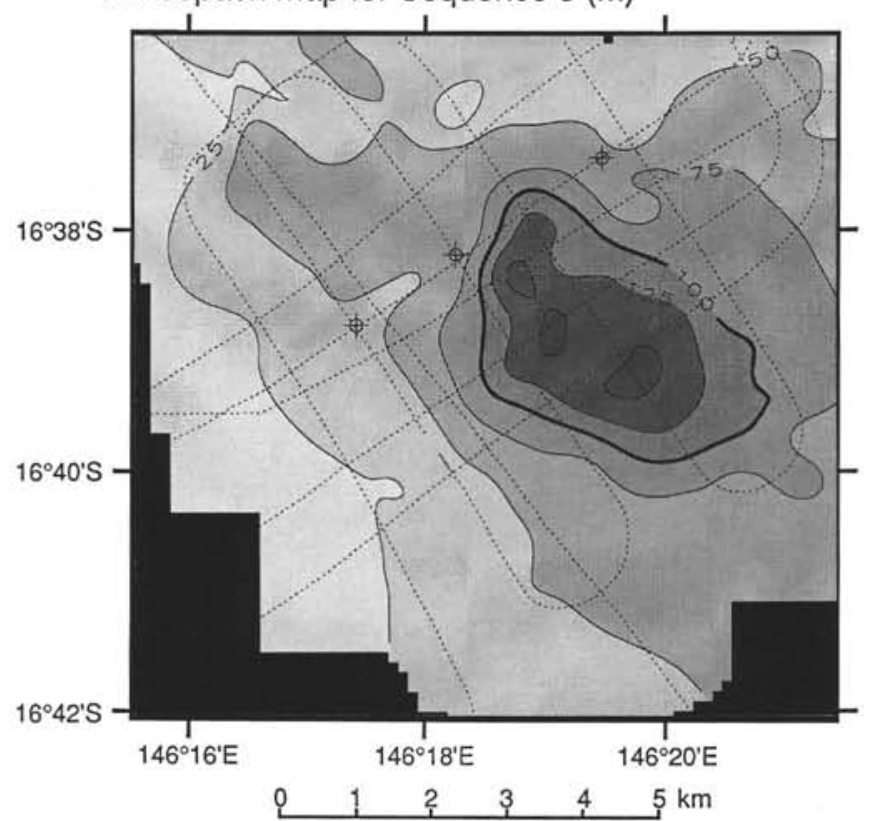

C. Isopach map for Sequence $7(\mathrm{~m})$

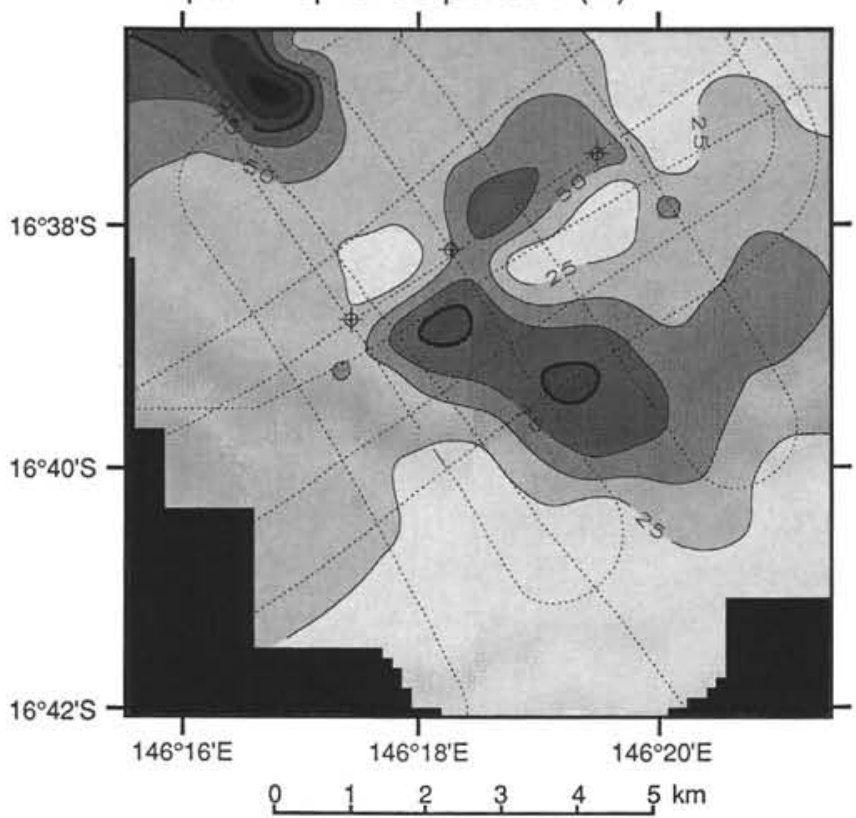

B. Isopach map for Sequence $6(\mathrm{~m})$

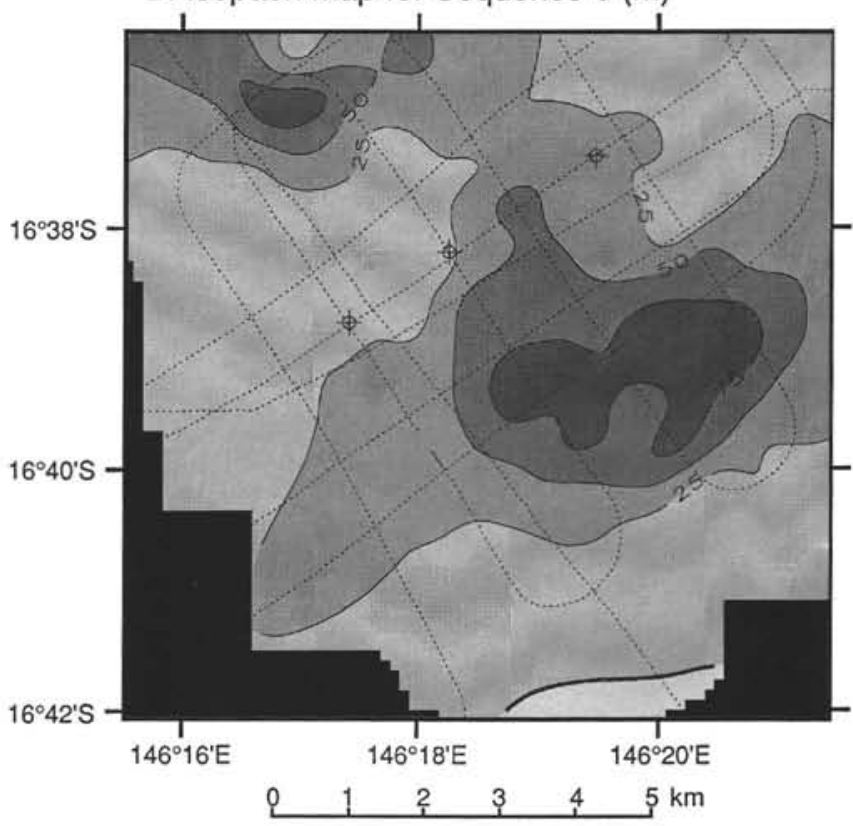

D. Isopach map for Sequence $8(\mathrm{~m})$

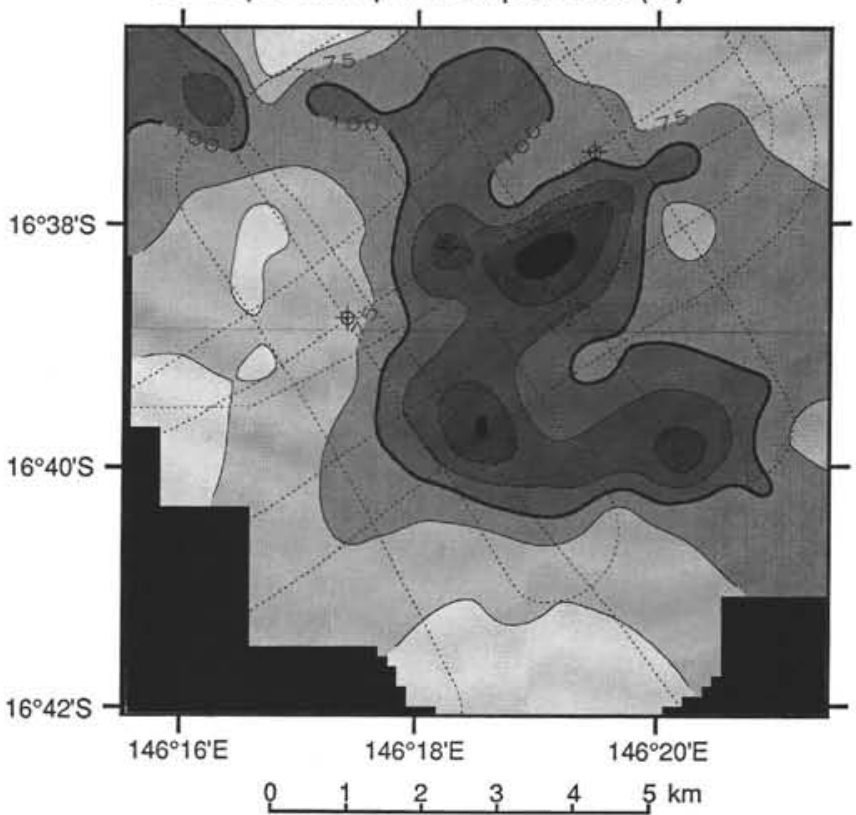

Figure 9. Isopach maps for Sequences 5 to 9 (A to E, respectively); all contours are in meters.

Sequence 4 also appears to be a toplap surface, with a reflector present at the shelf edge that thins and disappears landward. Small reef mounds are present on the shelf in three lines $(75 / 43 \mathrm{D}, 75 / 43 \mathrm{~F}$, and $75 / 43 \mathrm{~L}$ ).

Correlation with the detailed lithofacies logs at each site (Davies, McKenzie, Palmer-Julson, et al., 1991; Feary and Jarrard, this volume) show that the strong, continuous reflectors characteristic of Sequence 4 represent the boundaries between coarsening-upward cycles, with greenish-gray, calcareous, clayey mudstone grading up to thick beds of coarser bioclastic packstone (Fig. 3). Biostratigraphic correlation with Sites 820 and 821 shows that the 930 k.y. nannofossil datum occurs toward the top of Sequence 4 (Fig. 5); however, the next oldest datum, at 1.1 Ma, is well below the base of the sequence (Wei and Gartner, this volume). Therefore, we were only able to estimate the sequence duration assuming approximately constant sedimentation rates; a questionable assumption considering the time loss associated with the sequence boundary unconformities and onlap surfaces. Such a calculation provides a sequence age estimate of 0.76 to $1.01 \mathrm{Ma}$. Biostratigraphic correlation with Site 819 indicates that much of the section severely disrupted by slumping, between 60 and $160 \mathrm{mbsf}$, can be correlated with Sequence 4. Slump repetition of at least part of the sequence at this site is probable, although the absence of any distinctive marker beds and the coarseness of biostratigraphic markers makes identification of any repetition particularly difficult. 


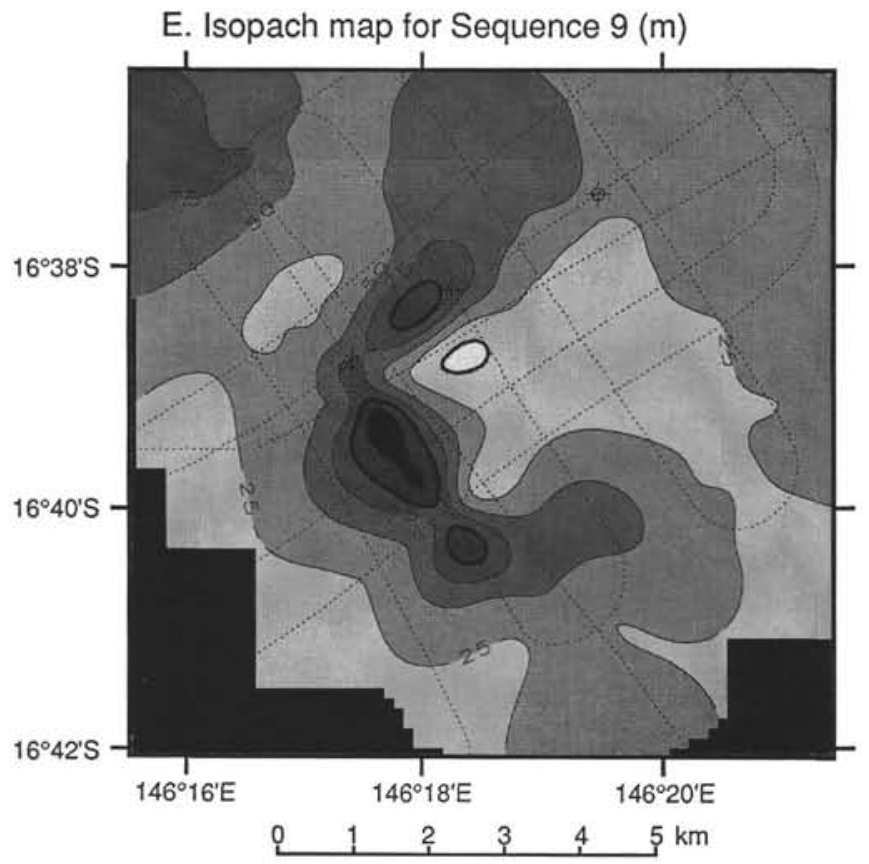

Figure 9 (continued).

\section{Progradational Package (Sequences 5 to 9)}

Sequences 5 to 9 record the filling in of broad, extensive submarine valleys underlying the present outer shelf to produce the predominantly flat shelf bathymetry at the base of Sequence 4, where valleys were restricted to the upper slope and shelf edge. Isopach maps of combined sequences (Figs. 8B, 8C) clearly record the progradational history of the margin, with the locus of deposition moving some 2.5 $\mathrm{km}$ seaward during the interval represented by these sequences. Although the seismic grid was centered on one such valley system, the northern edge of the grid extends into another submarine valley with similar obliquely progradational sediment geometries, indicating that similar valleys probably occurred at a number of places along the margin. Depocenters for each sequence are located within the upper parts of these broad valleys, with each sequence thinning landward, seaward, and also over the "divides" or promontories between valleys (Fig. 9).

The sequence boundaries identified within this progradational package are apparently continuous, relatively high-amplitude reflectors that can be traced over much or all of the seismic grid, including within the multiple. In most cases, they represent onlap surfaces and are therefore true unconformities (Mitchum, 1977). However, as noted above, in some cases we had to use apparently conformable reflectors that were traceable over most of the seismic grid as sequence boundaries to illustrate sediment package geometry.

Correlation with lithofacies at Sites 819 to 821 show that the progradational package represents stacked coarsening-upward cycles ranging from 15 to $60 \mathrm{~m}$ thick (Feary and Jarrard, this volume). These cycles occur as thin intervals of dark greenish-gray calcareous mudstone that grade up into much thicker, lighter-colored, calcareous, "chalky" packstone (Fig. 3).

\section{Sequence 5}

The sequence boundary marking the top of Sequence 5 is the most pronounced seismic discontinuity within the entire seismic grid. Reflectors at the top of the sequence are abruptly truncated, indicating that the upper sequence boundary represents an erosional unconformity. The basal sequence boundary is an onlap surface (e.g., Line

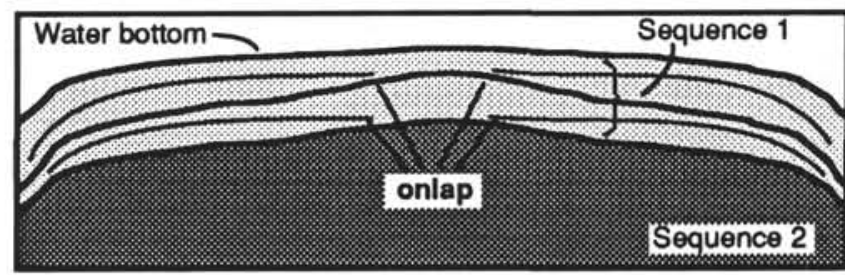

Figure 10. Schematic diagram illustrating stratal relationships along strike within Sequence 1 (based on Line 75/43J). Note the onlapping reflectors within each subsequence.

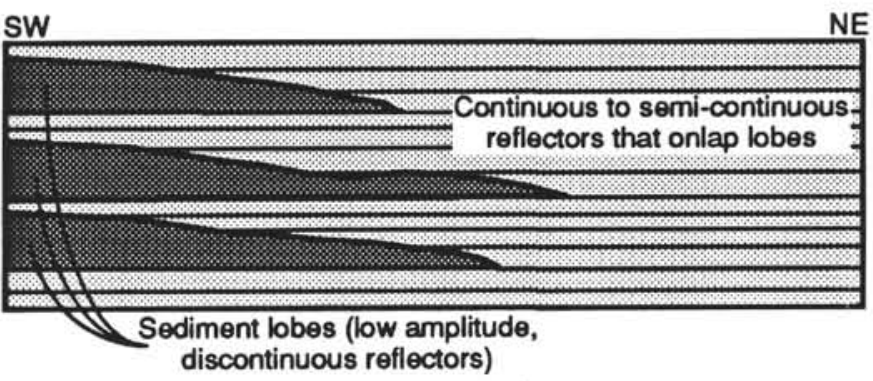

Figure 11. Schematic representation of stratal relationships within Sequence 3 on the outer shelf, showing the lobate geometry of inferred sediment lobes derived from the southwest, which have been onlapped by subparallel reflectors.

75/43D; CDPs 2350-2450) at the shelf edge, and also appears to be an erosional unconformity within canyons on the upper slope (Line 75/43P; CDPs 7950-8050). Sequence 5 reflectors predominantly have variably low to moderate amplitudes and appear discontinuous. Stratal relationships indicate that deposition occurred as a result of the alternation of drape (continuous reflectors) and onlap/infill (discontinuous reflectors) processes (e.g., Line 75/43J). The depocenter curves around the head of the submarine valley, with the thickest section occurring on the southern side of the valley (Fig. 9A). Small reefal mounds are relatively common within this sequence, occurring beneath the outer shelf in Lines 75/43D, 75/43F, 75/43J, 75/43L, and $75 / 43 \mathrm{~N}$.

The two highest-amplitude reflectors in Sequence 5 at Site 820 correspond to the boundaries between three coarsening-upward cycles. It is likely that additional coarsening-upward cycles are present within deeper, thicker parts of the sequence; however, slumping prevents direct correlation with Site 819. Biostratigraphic correlation shows that both the 1.1 and 1.27 Ma nannofossil datums occur toward the base of Sequence 5 (Fig. 5), although the 1.27 Ma datum is particularly difficult to locate precisely because the index species (Helicosphaera selli) is rare (Wei and Gartner, this volume). An approximate estimate for the duration of Sequence 5 , assuming broadly constant sedimentation rates, is from 1.01 to $1.3 \mathrm{Ma}$.

\section{Sequence 6}

As is the case with Sequence 5, the Sequence 6 depocenter curves around the head of the submarine valley, with the thickest section occurring on the southern side of the valley (Fig. 9B). The upper sequence boundary is the Sequence 5 basal onlap/erosional unconformity. The lower Sequence 6 boundary is simply a high-amplitude reflector that may be traced throughout the grid. The multiple conceals the nature of stratal relationships between the sequence boundaries and the additional reflectors present in the thicker parts of the sequence. Downslope, these additional reflectors thin and coalesce. Small reefal mounds are present within bathymetrically higher parts of Sequence 6 (Line 75/43D) on the northern margin of the grid. 
The lithofacies intersected within the ODP holes show that Sequence 6 represents a single coarsening-upward cycle at all three sites (Davies, McKenzie, Palmer-Julson, et al., 1991; Feary and Jarrard, this volume). As is the case with the overlying sequence, it is likely that additional coarsening-upward cycles are present within deeper, thicker parts of the sequence. Neither nannofossil nor planktonic foraminiferal biostratigraphic zonations are particularly useful for defining the age of Sequence 6 or deeper sequences. The $1.27 \mathrm{Ma}$ nannofossil datum occurs in Sequence 5 (Fig. 5), and the $1.48 \mathrm{Ma}$ datum is not encountered within any of the sites on the Great Barrier Reef margin (Wei and Gartner, this volume).

\section{Sequence 7}

Sequence 7 is characterized by relatively continuous, moderateamplitude reflectors. The upper boundary is the traceable reflector, which lacks any unconformable characteristics, that forms the base of Sequence 6. The lower sequence boundary is also a continuous traceable reflector, but truncated reflectors on the upper slope indicate that it is an offlap surface (e.g., Line 75/43P). The additional reflectors that make up the increased thickness at the depocenter thin and coalesce on the upper slope; they appear to onlap at the landward side of the grid, although the multiple largely obscures stratal relationships. Again, the depocenter is located in the upper part of a submarine valley and curves around the valley margins (Fig. 9C). Small reef mounds are present in the bathymetrically higher parts of the sequence in the north of the grid (Line 75/43D).

This sequence correspond to a single coarsening-upward cycle at Sites 820 and 821 and apparently to two coarsening-upward cycles nearer the depocenter at Site 819. Lack of biostratigraphic control precludes any estimation of the age of this sequence.

\section{Sequence 8}

The Sequence 8 depocenter appears to curve around the margins of the broad submarine valleys (Fig. 9D); however, the apparent gap in the depocenter isopachs at the valley head is largely a result of removal by erosion of the topmost part of the sequence rather than a reflection of an original depositional gap. This erosion is marked by truncated reflectors at the Sequence 7 basal unconformity. The sequence boundary at the base of Sequence 8 is a continuous, traceable reflector; although stratal relationships are obscured by the multiple, no evidence exists for this boundary being an unconformity. Small reefal mounds may be present toward the northern part of the grid (Line 75/43D), although again the presence of the multiple obscures these features sufficiently to make it difficult to be certain that these are real, rather than velocity pullup effects.

Sequence 8 corresponds to three coarsening-upward cycles at Site 821 and to two coarsening-upward cycles at Site 819 (Davies, McKenzie, Palmer-Julson, et al., 1991; Feary and Jarrard, this volume). The bottom of Hole $820 \mathrm{~B}$ intersects a single coarsening-upward cycle at the top of the sequence.

\section{Sequence 9}

Although the Sequence 9 depocenter lies within the broad submarine valley, the thickest parts of the sequence are more concentrated on the valley axis than in higher sequences (Fig. 9E). Because this sequence is almost entirely within the multiple, stratal relationships are largely obscured. Both upper and lower sequence boundaries are relatively continuous, traceable reflectors that display no obvious evidence of unconformity.

Only the uppermost part of this sequence was intersected at Sites 819 and 821 (Fig. 3). Poor biostratigraphic control means that it is only possible to determine that the age of the sequence is between 1.27 and $1.48 \mathrm{Ma}$ (Wei and Gartner, this volume).

\section{DISCUSSION AND CONCLUSIONS}

The geometry of the Pleistocene sequences intersected at Sites 819 to 821 reflects shifting loci of deposition under the influence of two profoundly different sedimentary regimes. The transition from obliquely progradational to aggradational sequence geometries represents a fundamental change in the manner in which sediment accumulated on this margin. Clearly, a major factor controlling the geometry of the depositional sequences, particularly the obliquely progradational sequences, was the shape of the pre-existing bathymetric surface on which the sedimentary packages were deposited. The broad submarine valleys apparent throughout the lower seismic sequences probably were formed during a period when the shelf was relatively narrow and lacked any substantial barrier at the shelf edge, so that drainage systems on land could feed into, and erode, valleys on the upper slope and outer shelf. Depth maps (not presented here) of prominent reflectors much deeper beneath the outer shelf show a similar pattern of broad submarine valleys and slightly narrower intervening promontories, and the shape of progradational sequence depocenters (Fig. 9) shows that although some concentration of sediment is evident near the valley axis, there was also sufficient deposition on the valley margins and between valleys to perpetuate the broad valley shape. Nevertheless, at the conclusion of Sequence 5, obliquely progradational deposition had resulted in the restriction of the submarine valleys to the upper slope and shelf edge, so that a relatively broad outer shelf had developed.

The obliquely sigmoidal progradational package (Sequences 5 to 9) represents relatively rapid deposition controlled by a variable baselevel. Even with the multiple concealing or interfering with stratal relationships in the older sequences, it is clear that cyclic alternation of sediment onlap and drape is repeated throughout the progradational package. Onlap represents a lowering of depositional base-level (Vail et al., 1977a; Christie-Blick, 1991) which caused the locus of sedimentation to step off the paleoshelf edge and down into the submarine valley system, whereas drape represents a relative rise in depositional base-level that permitted the sediment to be deposited more evenly over the entire outer shelf and upper slope. The progradational package isopach maps (Fig. 9) also show that, in most cases, sediment was not point-sourced within the region of the seismic grid, but rather was available around the valley margins. The concentration of sediment on the southern side of the valley margins for a number of the progradational sequences suggests that reworking of shelf sediment into the valleys was at least partly due to currents from the south.

Estimates of paleodepth from benthic foraminifer studies (Davies, McKenzie, Palmer-Julson, et al., 1991) provide a key element for correlating the cyclic deposition, represented by the multiple coarsening-upward cycles characteristic of the obliquely progradational sequences, with the base-level variations indicated by seismic stratal relationships. Paleodepth determinations show that whereas Site 819 contains upper bathyal $(200-600 \mathrm{~m})$ indicators throughout the succession, Sites 820 and 821 contain both neritic $(<200 \mathrm{~m})$ and upper bathyal assemblages (Davies, McKenzie, Palmer-Julson, et al., 1991). In particular, the faunas at Site 820 consistently indicate upper bathyal paleodepths in lower parts of the coarsening-upward cycles and outer neritic (100-200 m) paleodepths in higher parts of the cycles. The coarsening-upward cycles therefore indicate repeated shallowingupward, regressive cycles, with the thin, fining-upward tops to each cycle representing deepening. Accordingly, it is possible to infer the relationship between this regressive cyclicity and the seismic sequence characteristics for each component of depositional base-level variation (Feary and Jarrard, this volume) as follows (Fig. 12):

1. Base-level rise: produced a relatively condensed, muddy, onlapping sequence, with coarse bioclastic detritus either not produced on the inner shelf, or trapped there; the mud component was the "background" sediment deposited during all stages. 

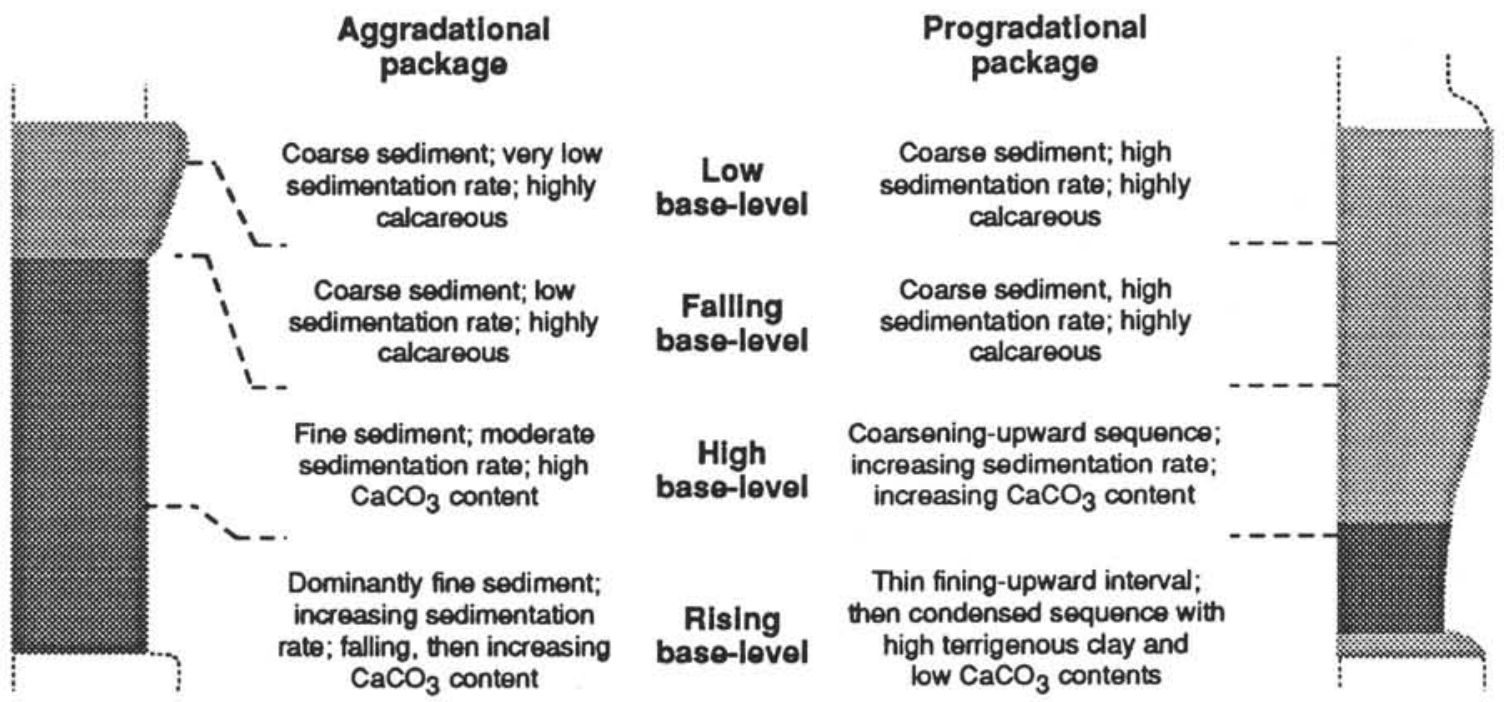

Figure 12. Summary of lithofacies characteristics for different parts of the base-level cycle for obliquely progradational (Sequences 5 to 9) and aggradational (Sequences 1 to 3) components of the outer shelf succession at Site 820. Based on data and interpretations in Feary and Jarrard (this volume) and Peerdeman and Davies (this volume).

2. Base-level high: produced the rapidly coarsening part of each cycle, as the coarse bioclastic detritus that was produced on the shelf during this and the rising base-level stage could be moved offshore by shelf currents and storms and deposited as a sediment drape.

3. Base-level fall: led to continued deposition of both coarse and fine detritus, with a higher sedimentation rate as drainage systems attempted to maintain equilibrium.

4. Base-level low: produced continued deposition of both coarse and fine detritus, particularly concentrated as onlapping reflectors within the upper parts of submarine valleys below the shelf edge; this stage was abruptly terminated by the initiation of a base-level rise, which produced the thin fining-upward top to each cycle.

It is apparent, therefore, that this depositional sequence accounts for both the relatively thick, coarser component within each cycle and the position of the coarsening-upward transition toward the base of each cycle (Fig. 3; Feary and Jarrard, this volume).

The aggradational package (Sequences 1 to 3 ) similarly reflects the dominant influence of depositional base-level control on sediment accumulation. Both Sequences 1 and 3 show onlapping stratal relationships, which indicates that base-level falls were followed by rises to produce onlap (Vail et al., 1977a; Christie-Blick, 1991). The extensive sediment lobes characteristic of Sequence 3 apparently represent baselevel falls, with the onlapping reflectors representing later base-level rises. Base-level control of Sequence 2 deposition is less obvious; however, the cyclic increases in carbonate content within the muddy intervals (Feary and Jarrard, this volume), by analogy with the finergrained components of the progradational package, are likely to represent rising and high base-levels. By contrast, falling and low baselevels are represented by relatively thin, coarse, bioclastic wackestone beds, indicating either that abundant coarse bioclastic material was not being produced on the inner shelf, a seemingly unlikely situation, or that it was mostly trapped on the shelf during base-level falls. Baselevel control during Sequence 1 deposition is more obvious, with the major reflectors representing thicker, more calcareous, bioclastic wackestone beds that were deposited during major base-level falls, and the onlapping reflectors representing thinner, coarse, bioclastic wackestone beds that were deposited during slight base-level falls within overall rises.

Therefore, despite the fundamentally different seismic geometries present in the upper part of the sedimentary succession beneath the outer shelf and upper slope, it is apparent that (1) broadly similar sediment was available throughout the succession (bioclastic detritus and a mixture of calcareous and terrigenous mud), although a greater proportion of coarse bioclastic detritus occurs in the lower parts of the succession (Sequences 4 to 9), and (2) depositional base-level control was the dominant factor controlling compositional and grainsize variations for both types of geometry (Fig. 12).

Variations in sedimentation rate (Table 1) provide an entirely consistent and plausible explanation for the markedly different seismic geometries apparent in the upper and lower parts of the succession. Using the thickest parts of each sequence, the sedimentation rate for Sequences 1 to 3 averaged approximately $26 \mathrm{~cm} / \mathrm{k}$.y., compared with approximately $60 \mathrm{~cm} / \mathrm{k}$.y. for Sequence 4 and an average of at least $143 \mathrm{~cm} / \mathrm{k} . \mathrm{y}$. for Sequences 5 to 9 . The possible causes for this major reduction at about Sequence 4 time are either that the sediment supply onto the outer shelf remained constant, with most of the sediment being removed downslope, or that a major change occurred in the rate of sediment supply. Had most of the sediment been removed downslope, it should have been accompanied by substantial erosion. In the absence of any evidence for major erosion, it is reasonable to infer that a marked reduction in the supply of sediment onto the outer shelf took place. The most likely explanation for this reduction is that initiation of outer Great Barrier Reef growth created a barrier that essentially trapped inner shelf and terrigenous sediment inshore, and that also excluded high-energy events that might otherwise have eroded inner shelf detritus and moved it seaward. Even most of the material produced at the outer reef would have been moved landward (Davies, 1983) once a barrier existed. Although the marked erosional unconformity at the base of Sequence 4 is the most prominent break on the seismic sections (see Appendix), sedimentation rate data suggest that although barrier growth may have been initiated at this time, it was probably not an effective barrier until the end of Sequence 4 deposition. Therefore, growth of the central Great Barrier Reef probably commenced during the base-level rise that immediately followed the base-level drop and erosion at the top of Sequence 5 (approximately $1.01 \mathrm{Ma}$ ) and that an effective barrier existed by the end of Sequence 4 (approximately $0.76 \mathrm{Ma}$ ). From this time onward, terrigenous sediment, inner shelf sediment, and the abundant bioclastic material generated by the reefs would all have been retained and reworked on the inner shelf and only moved downslope through the few major breaks in the outer barrier reef.

The presence of reefal detritus within ODP cores cannot be used as corroborative evidence to confirm initiation of reef growth, because 
reefal mounds are present within the upper parts of the progradational package (Sequences 5 to 7 ) and were undoubtedly also present farther landward on the inner and middle shelf (e.g., Pleistocene sequence drilled at Michaelmas Cay, immediately north of Grafton Passage; see Richards and Hill, 1942). However, seismic data do provide some corroboration. Although caution in interpretation is required because of the strong multiple and the difficulty in transmitting seismic energy through the hard carbonate surface of Grafton Passage, it does appear that several of the highest-amplitude reflectors at the Sequence 4 level and lower pass landward under the reef (Lines 75/43A to 75/43D), indicating that at least this part of the reefal barrier is a more recent feature than these reflectors.

In both siliciclastic and carbonate depositional systems, aggradational and progradational seismic geometries are usually interpreted as reflecting the interaction of sediment supply and accommodation, with aggradation resulting from a relative rise in sea-level sufficient to accommodate sediment supply, and progradation resulting from nearshore accommodation constraints causing basinward movement of the locus of deposition (Kendall \& Schlager, 1981; Vail, 1987; Jervey, 1988; Posamentier and Vail, 1988; Sarg, 1988; Meyer, 1989; ChristieBlick, 1991). Although eustatic fluctuations of sea-level are undoubtedly the dominant component of base-level movements recorded by lithofacies variations on the outer shelf and upper slope adjacent to the Great Barrier Reef, there are no indications that accommodation was a direct controlling factor. Paleodepth data (Davies, McKenzie, Palmer-Julson, et al., 1991) indicate that the depositional site was at outer neritic depths (100-200 m) or deeper during the shallowest parts of base-level cycles, too deep for wave-base erosion to be factor. However, accommodation may have played an indirect part, by exerting some control on the supply of sediment from the inner shelf on the scale of individual sedimentary cycles, and by intensifying the shelf currents which reworked detritus into the broad submarine valleys in the lower part of the succession during low sea-level periods. In conclusion, stratal relationships and lithofacies correlation indicate that whereas variations in depositional base-level controlled the deposition of particular lithofacies, the rate of sediment supply provided the fundamental control on the overall geometry (aggradation vs progradation) of the seismic sequences.

\section{ACKNOWLEDGMENTS}

The authors acknowledge the cooperation of the Rig Seismic officers and crew and AGSO technical and scientific personnel during collection of the site-survey seismic data, and the assistance of AGSO's Seismic Processing Center personnel during data processing. Data interpretation was significantly assisted by the individuals and organizations which provided time and assistance on LANDMARK interactive workstations: John Denham and Carole Wright at BHP Petroleum Pty. Ltd., Melbourne; Stephanie Staples, Andre Droxler, and Pete Vail at Rice University, Houston; and personnel at Landmark Graphics International offices in Houston and Sydney. Figure 4 and the Appendix were prepared by Jim Mason at the AGSO Cartographic Services Unit. The manuscript was reviewed by $\mathrm{S}$. Greenlee, G. Eberli, and S. Stewart. Finally, discussions and interaction with colleagues on board the JOIDES Resolution contributed to the data and ideas presented here. Feary, Symonds, and Pigram publish with permission of the Executive Director, Australian Geological Survey Organisation.

\section{REFERENCES $*$}

Brooks, G.R., and Holmes, C.W., 1989. Recent carbonate slope sediments and sedimentary processes bordering a non-rimmed platform: southwest Florida continental margin. In Crevello, P.D., Wilson, J.L., Sarg, J.F., and Read, J.F. (Eds.), Controls on Carbonate Platform and Basin Development. Spec. Publ.-Soc. Econ. Paleontol. Mineral., 44:259-272.
Brown, L.F., and Fisher, W.L., 1977. Seismic-stratigraphic interpretation of depositional systems: examples from Brazil rift and pull-apart basins. In Payton, C. E. (Ed.), Seismic Stratigraphy-Applications to Hydrocarbon Exploration. AAPG Mem., 26:213-248.

Christie-Blick, N., 1991. Onlap, offlap, and the origin of unconformitybounded depositional surfaces. Mar. Geol., 97:35-56.

Davies, P.J., 1983. Reef growth. In Barnes, D.J. (Ed.), Perspectives on Coral Reefs: Canberra (Aust. Inst. Mar. Sci./Brian Clouston), 69-106.

Davies, P.J., McKenzie, J.A., Palmer-Julson, A., et al., 1991. Proc. ODP, Init. Repts., 133: College Station, TX (Ocean Drilling Program).

Davies, P.J., Symonds, P.A., Feary, D.A., and Pigram, C.J., 1987. Horizontal plate motion: a key allocyclic factor in the evolution of the Great Barrier Reef. Science, 238:1697-1700.

1989. The evolution of the carbonate platforms of northeast Australia. In Crevello, P.D., Wilson, J.L., Sarg, J.F., and Read, J.F. (Eds.), Controls on Carbonate Platform and Basin Development. Spec. Publ.Soc. Econ. Paleontol. Mineral., 44:233-258.

Doglioni, C., Bosellini, A., and Vail, P.R., 1990. Stratal patterns: a proposal of classification and examples from the Dolomites. Basin Res., 2:83-95.

Erlich, R.N., Barrett, S.F., and Ju, G.B., 1990. Seismic and geologic characteristics of drowning events on carbonate platforms. AAPG Bull., 74:1523-1537.

Feary, D.A., Davies, P.J., Pigram, C.J., and Symonds, P.A., 1991. Climatic evolution and control on carbonate deposition in Northeast Australia. Palaeogeogr., Palaeoclimatol., Palaeoecol., 89:341-361.

Feary, D.A., Pigram, C.J., Davies, P.J., Symonds, P.A., Droxler, A.W., and Peerdeman, F., 1990. Ocean Drilling Program-Leg 133-Northeast Australia safety package. Bur. Miner. Resour. Aust. Rec., 1990/6.

Jervey, M.T., 1988. Quantitative geological modeling of siliciclastic rock sequences and their seismic expression. In Wilgus, C.K., Hastings, B.S., Posamentier, H.W., Van Wagoner, J.C., Ross, C.A., and Kendall, C.G.St.C. (Eds.), Sea-Level Changes: An Integrated Approach. Spec. Publ.-Soc. Econ. Paleontol. Mineral., 42:47-69.

Kendall, C.G.St.C., and Schlager, W., 1981. Carbonates and relative changes in sea level. In Cita, M.B., and Ryan, W.B.F. (Eds.), Carbonate Platforms of the Passive-type Continental Margins, Present and Past. Mar. Geol., $44: 181-212$.

McGovney, J.E., Radovich, B.J., 1985. Seismic stratigraphy and facies of the Frigg Fan Complex. In Berg, O.R., and Woolverton, D.G. (Eds.), Seismic Stratigraphy II: An Integrated Approach to Hydrocarbon Exploration. AAPG Mem., 39:139-154.

Meyer, F.O., 1988. Siliciclastic influence on Mesozoic platform development: Baltimore Canyon Trough, Western Atlantic. In Wilgus, C.K., Hastings, B.S., Kendall, C.G.St.C., Posamentier, H., Ross, C.A., and Van Wagoner, J. (Eds.), Sea-level Changes: An Integrated Approach. Spec. Publ.-Soc. Econ. Paleontol. Mineral., 42:213-232.

Mitchum, R.M., Jr., 1977. Seismic stratigraphy and global changes of sea level, Part 11: glossary of terms used in seismic stratigraphy. In Payton, C.E. (Ed.), Seismic Stratigraphy-Applications to Hydrocarbon Exploration. AAPG Mem., 26:205-212.

Mitchum, R.M., Jr., Vail, P.R., and Thompson, S., III, 1977. Seismic stratigraphy and global changes of sea level, Part 2: the depositional sequence as a basic unit for stratigraphic analysis. In Payton, C.E. (Ed.), Seismic Stratigraphy-Applications to Hydrocarbon Exploration. AAPG Mem., 26:53-62.

Posamentier, H.W., and Vail, P.R., 1988. Eustatic control on clastic deposition II. Sequence and systems tracts models. In Wilgus, C.K., Hastings, B.S., Kendall, C.G., Posamentier, H., Ross, C.A., and Van Wagoner, J. (Eds.), Sea-level Changes: An Integrated Approach. Spec. Publ.-Soc. Econ. Paleontol. Mineral., 42:125-154.

Richards, H.S., and Hill, D., 1942. Great Barrier Reef bores, 1926 and 1937: descriptions, analyses and interpretations. Rep. Great Barrier Reef Comm., $5: 1-122$.

Saito, Y., 1991. Sequence stratigraphy on the shelf and upper slope in response to the latest Pleistocene-Holocene sea-level changes off Sendai, northeast Japan. In Macdonald, D.I.M. (Ed.), Sedimentation, Tectonics and Eustasy: Sea-level Changes at Active Margins. Spec. Publ. Int. Assoc. Sedimentol., 12:133-150.

\footnotetext{
Abbreviations for names of organizations and publication titles in ODP reference lists follow the style given in Chemical Abstracts Service Source Index (published by American Chemical Society).
} 
Sarg, J.F., 1988. Carbonate sequence stratigraphy. In Wilgus, C.K., Hastings, B.S., Kendall, C.G.St.C., Posamentier, H., Ross, C.A., and Van Wagoner, J. (Eds.), Sea-Level Changes: An Integrated Approach. Spec. Publ.-Soc. Econ. Paleontol. Mineral., 42:155-181.

Symonds, P.A., Davies, P.J., and Parisi, A., 1983. Structure and stratigraphy of the central Great Barrier Reef. BMR J. Aust. Geol. Geophys., 8:277-291.

Vail, P.R., 1987. Seismic stratigraphy interpretation using sequence stratigraphy. Part 1: Seismic stratigraphy interpretation procedure. In Bally, A.W. (Ed.), Atlas of Seismic Stratigraphy (Vol. 1). AAPG Stud. Geol., 27:1-10.

Vail, P.R., Mitchum, R.M., Jr., and Thompson, S., III, 1977a. Seismic stratigraphy and global changes of sea level. Part 3: Relative changes of sea level from coastal onlap. In Payton, C.E. (Ed.), Seismic Stratigraphy-Applications to Hydrocarbon Exploration. AAPG Mem., 26:63-81.

1977b. Seismic stratigraphy and global changes of sea level. Part 4: global cycles of relative changes of sea level. In Payton, C.E. (Ed), Seismic Stratigraphy-Applications to Hydrocarbon Exploration. AAPG Mem., 26:83-97.
Van Wagoner, J.C., Mitchum, R.M., Campion, K.M., and Rahmanian, V.D., 1990. Siliciclastic Sequence Stratigraphy in Well Logs, Cores, and Outcrops: Concepts for High-Resolution Correlation of Time and Facies. AAPG Methods Explor. Ser., 7.

Date of initial receipt: 7 May 1992

Date of acceptance: 18 January 1993

Ms 133SR-250

\section{APPENDIX}

Seismic profiles and sequence interpretations for the site-survey seismic grid at Sites 819 to 821, on the Great Barrier Reef outer shelf and upper slope. The locations of each line part are shown in Figure 2 (Note that these profiles are highly reduced and, as a consequence, only the major elements of our interpretation can be shown). 
D.A. FEARY ET AL.

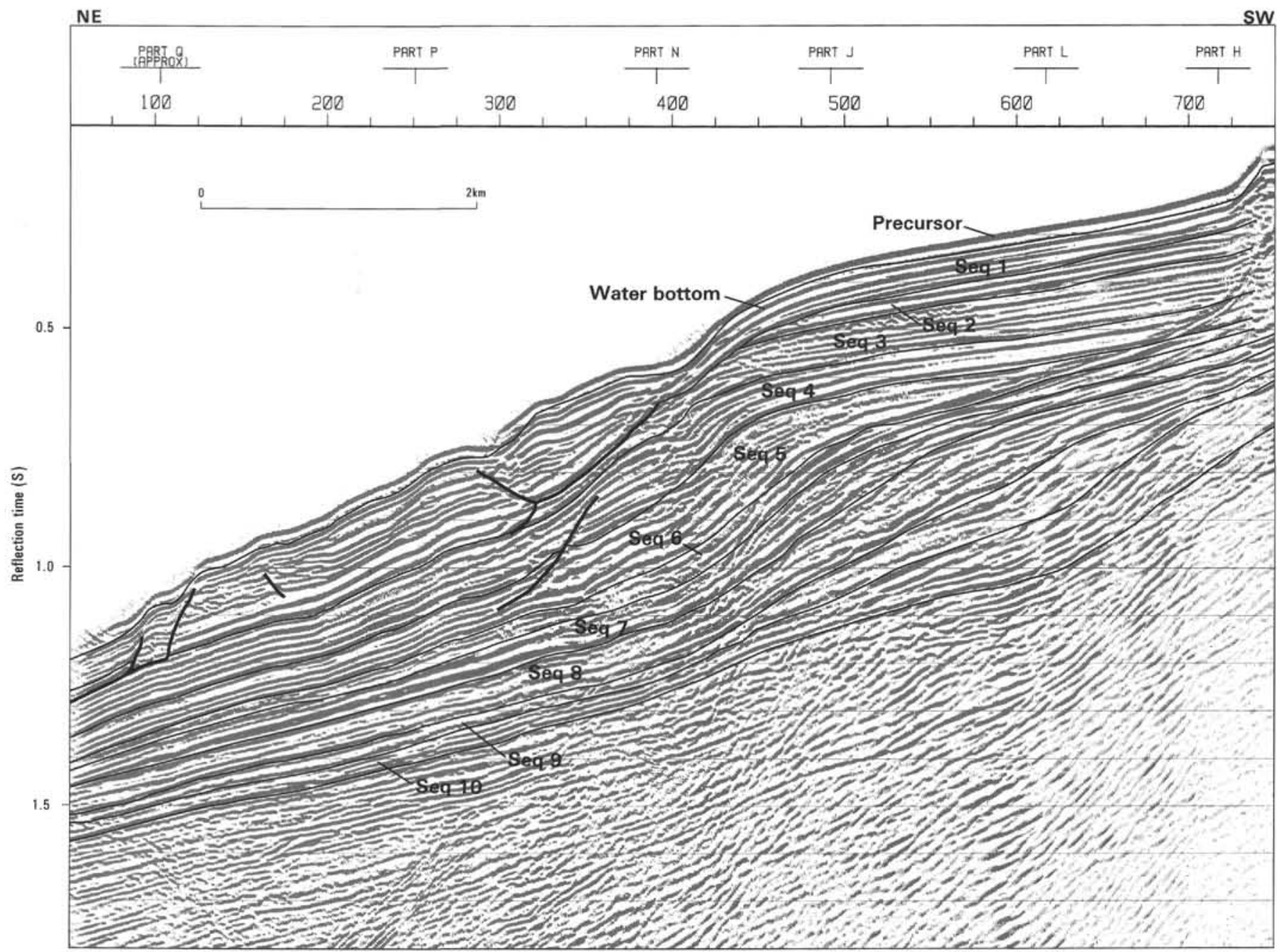

Sequence boundary

Fault/slump surface

$23 / 09 / 314$ 
FACIES GEOMETRY, GREAT BARRIER REEF

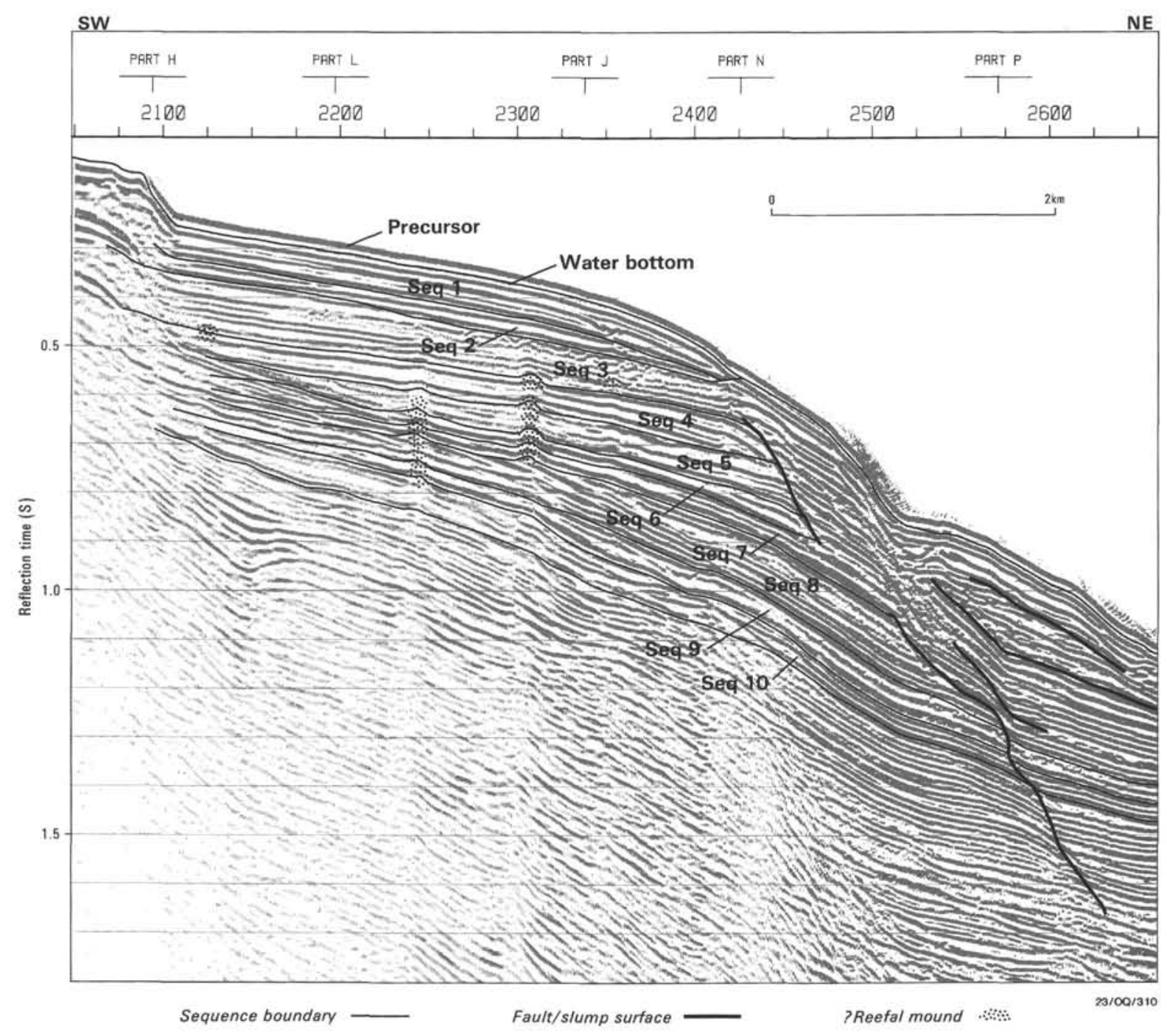


D.A. FEARY ET AL.

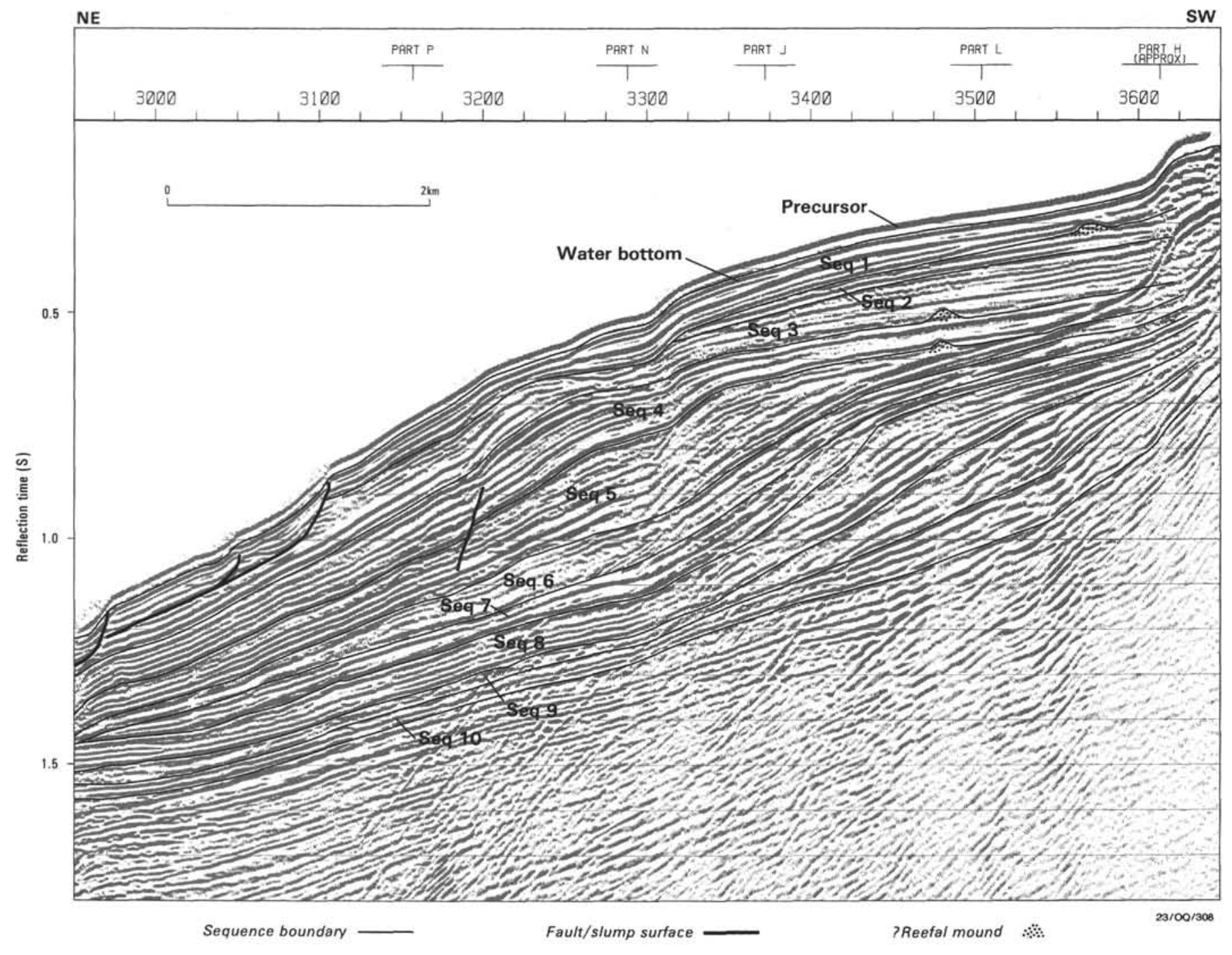




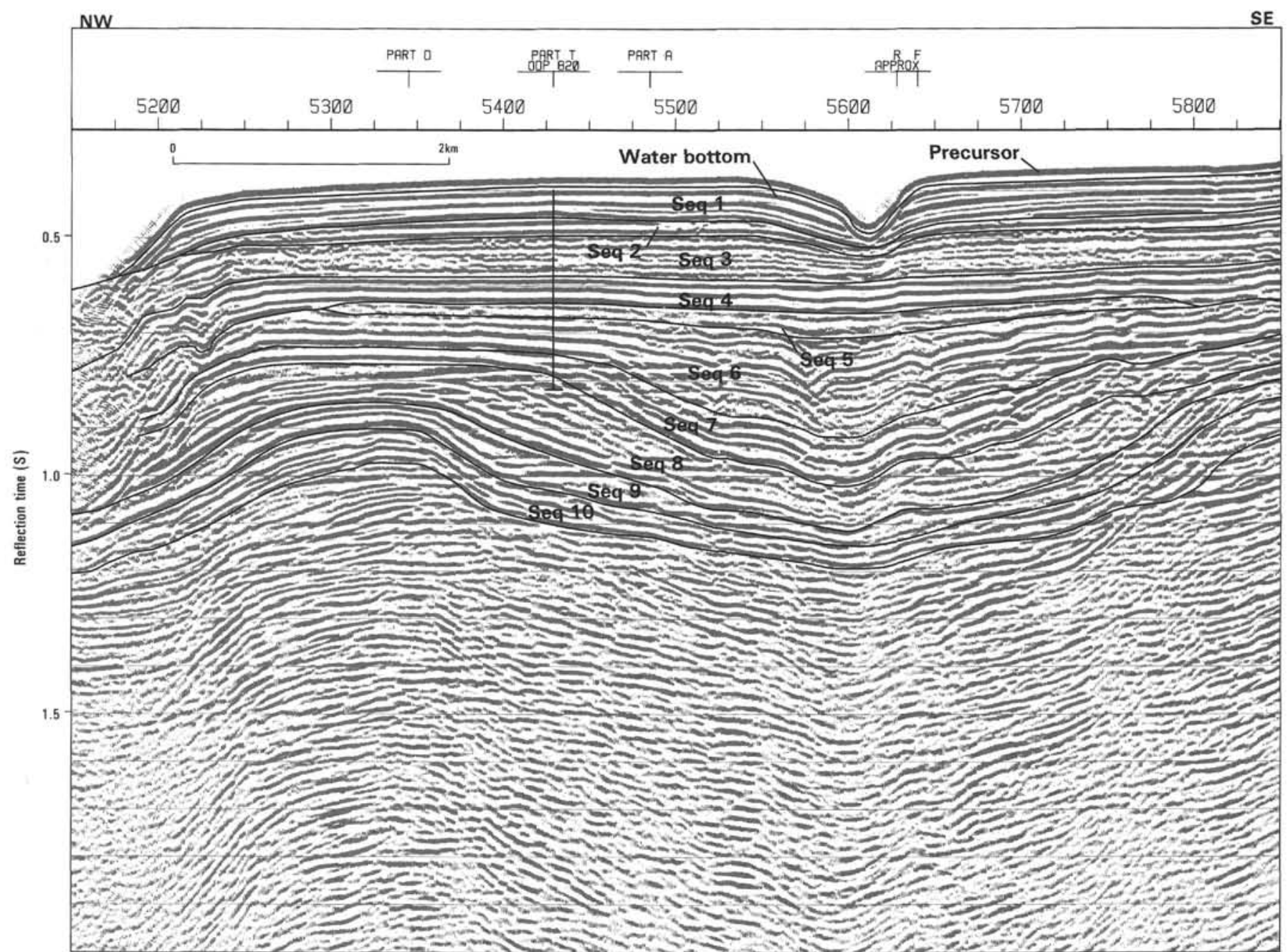




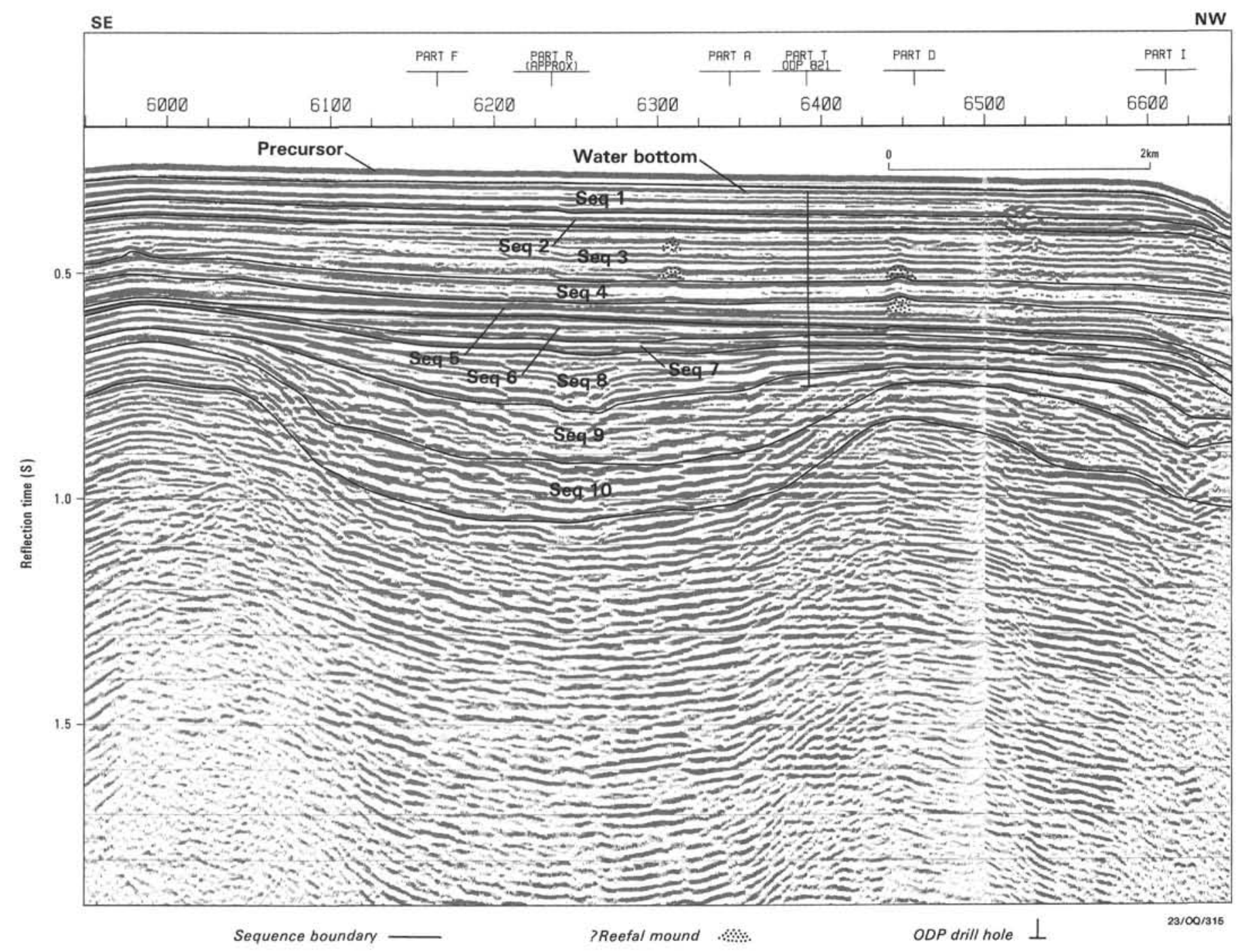


FACIES GEOMETRY, GREAT BARRIER REEF

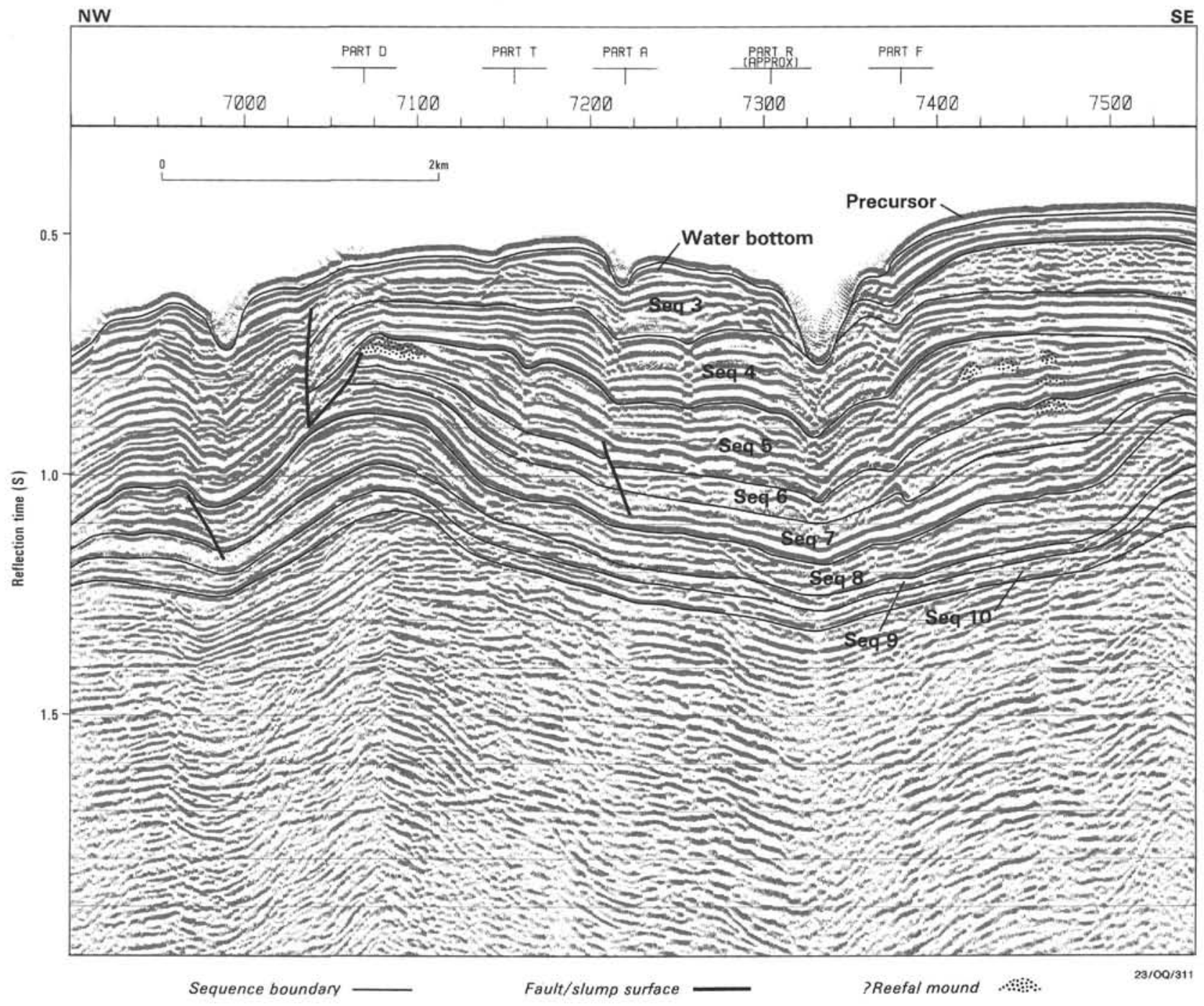




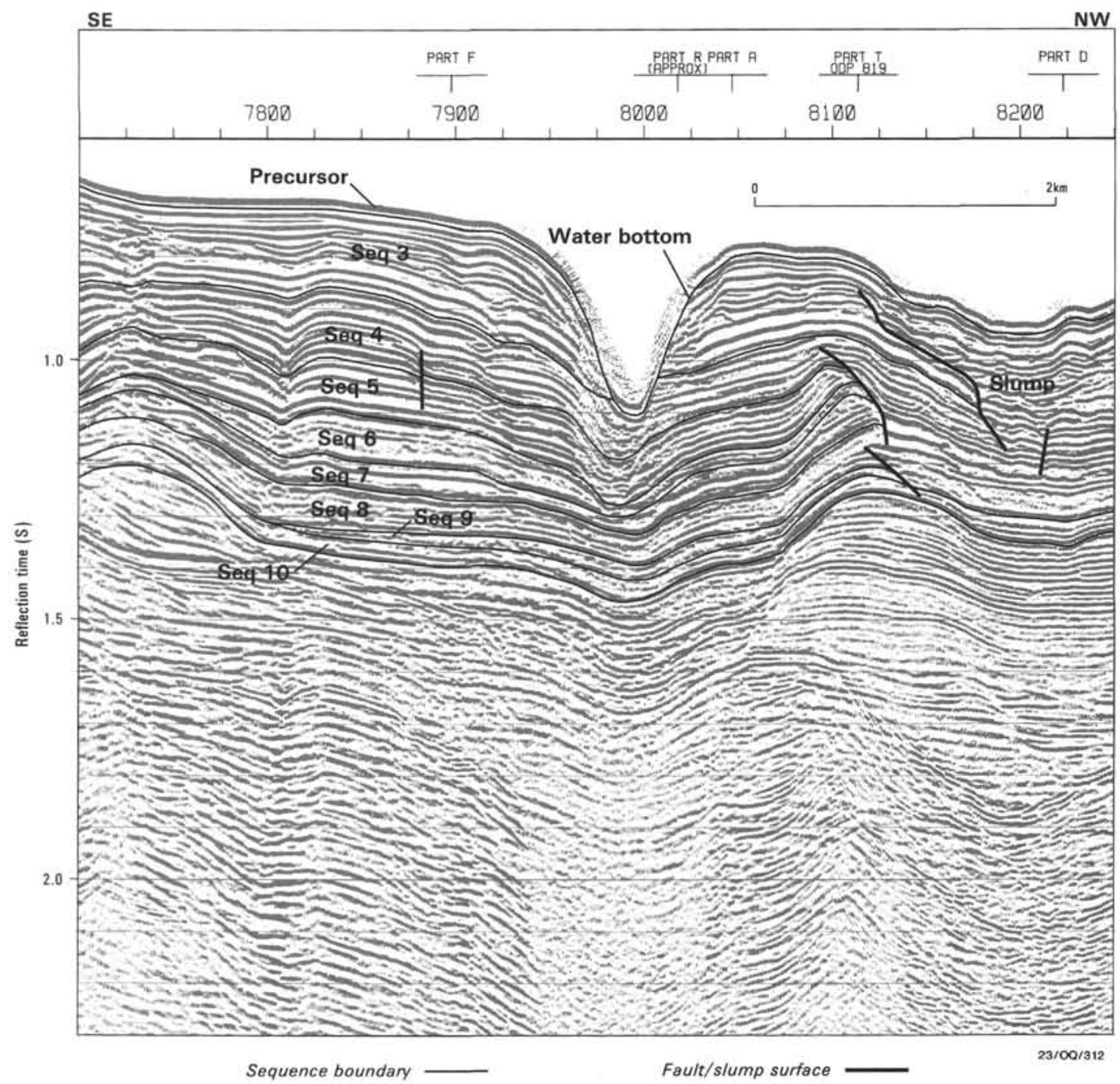




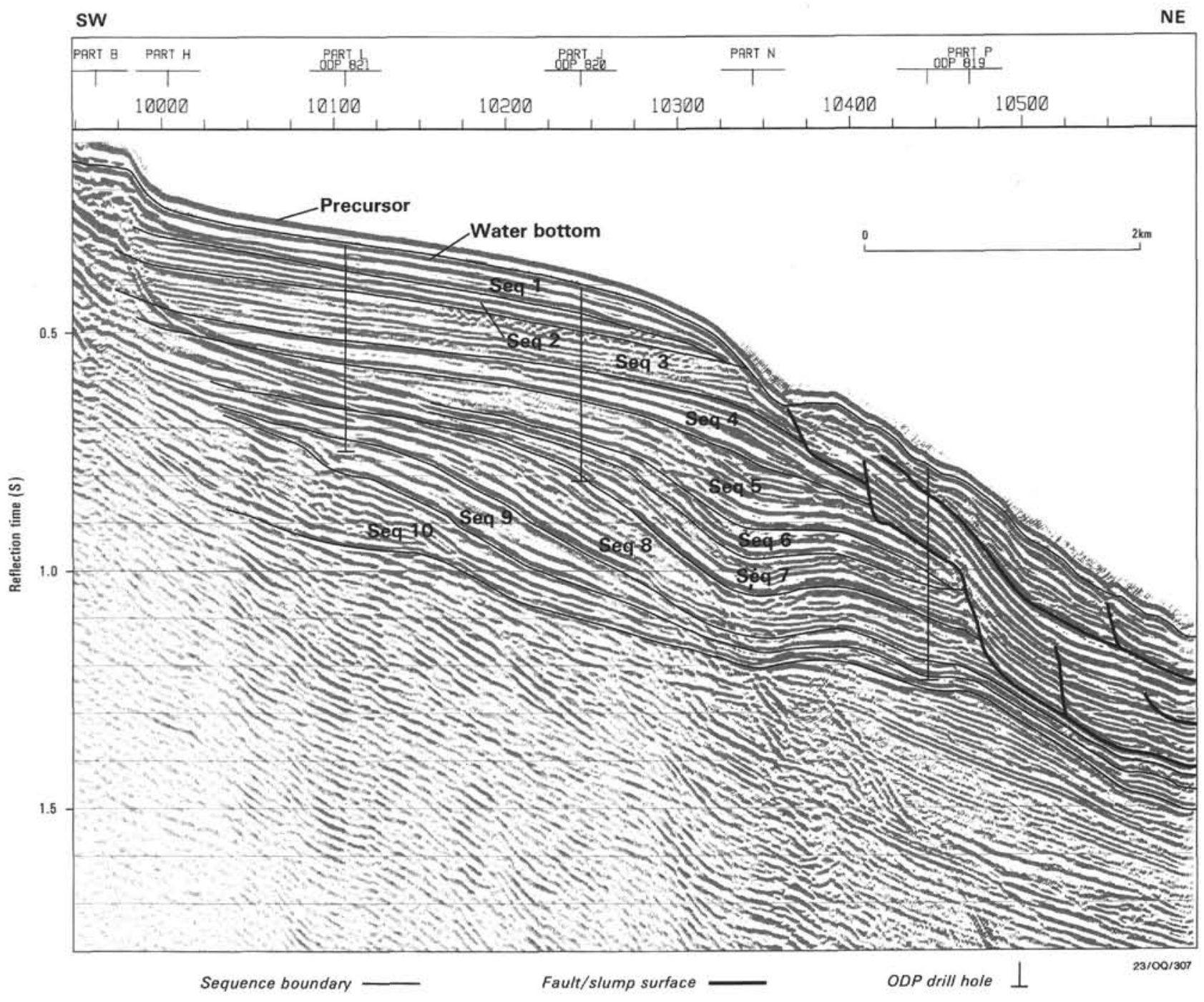

